\title{
Shootin1 Acts in Concert with KIF20B to Promote Polarization of Migrating Neurons
}

\author{
Tamar Sapir, ${ }^{1}$ Talia Levy, ${ }^{1}$ Akira Sakakibara, ${ }^{2}$ Aharon Rabinkov, ${ }^{3}$ Takaki Miyata, ${ }^{2}$ and Orly Reiner ${ }^{1}$ \\ ${ }^{1}$ Department of Molecular Genetics, Weizmann Institute of Science, 76100 Rehovot, Israel, ${ }^{2}$ Department of Anatomy and Cell Biology, Nagoya University \\ Graduate School of Medicine, Showa, Nagoya 466-8550, Japan, and ${ }^{3}$ Biological Services Unit, Weizmann Institute of Science, 76100 Rehovot, Israel
}

\begin{abstract}
Shootin1 has been ascribed a role in regulating polarization of primary hippocampal neurons. To better understand the possible role of Shootin 1 in the developing brain, we identified a member of the kinesin superfamily, KIF20B, as a novel Shootin1 interacting protein and a potential mediator of Shootin1 interaction with microtubules. KIF20B/Shootin1 binding was mapped to a 57 aa KIF20B sequence, which was used as a dominant-negative fragment. Direct interaction between that peptide (MBD) and Shootin1 was confirmed by surface plasmon resonance-based technology and the affinity was determined in the $10^{-7} \mathrm{M}$ range. The proteins are expressed in the developing brain and formed a complex in vivo based on coimmunoprecipitation experiments and coimmunostaining in primary neurons. In primary hippocampal neurons Kif20b knockdown reduced Shootin1 mobilization to the developing axon, as evidenced by immunostaining and fluorescence recovery after photobleaching analysis, suggesting that Shootin1 is a novel KIF20B cargo. shRNA targeting of Shootin1 reduced PIP3 accumulation in the growth cone, as did Kif20b shRNA. In the developing mouse brain, Kif20b knockdown or expression of the KIF20B minimal binding domain inhibited neuronal migration, and in vivo migration assays suggested that Shootin1/ Kif20b acts in the same genetic pathway. Time-lapse imaging of multipolar cells in the subventricular zone revealed that downregulating levels of either Shootin1 or Kif20b hindered the transition from multipolar to bipolar cells. Collectively, our data demonstrate the importance of the Shootin1/KIF20B interaction to the dynamic process of pyramidal neuronal polarization and migration.
\end{abstract}

\section{Introduction}

During cortical development neurons born in the proliferative zones of the dorsal telencephalon migrate radially toward the cortical pial surface (Rakic, 1972; Hatten, 1999, 2002; Miyata et al., 2001; Tamamaki et al., 2001; Nadarajah et al., 2001, 2002, 2003; Tabata and Nakajima, 2003; Kriegstein and Noctor, 2004; Ayala et al., 2007). Neurons born relatively late during corticogenesis reside in more superficial layers, establishing an insideout organization (Angevine and Sidman, 1961; McConnell, 1991). Cortical neuroblasts adopt a transient multipolar morphology preceding migration along radial glia (Tabata and Nakajima, 2003; LoTurco and Bai, 2006; Tabata et al., 2009). The transition between the multipolar morphology and bipolar morphology is vulnerable to genetic perturbations, and the knock-

Received Nov. 23, 2012; revised May 7, 2013; accepted June 8, 2013.

Author contributions: T.S., T.L., A.S., and 0.R. designed research;T.S., T.L., A.S., and A.R. performed research;A.S. contributed unpublished reagents/analytic tools; T.S., T.L., A.R., and 0.R. analyzed data; T.S., T.M., and 0.R. wrote the paper.

O.R. is an Incumbent of the Berstein-Mason professorial chair of Neurochemistry. Our research has been supported in part by the Israel Science Foundation (Grant no. 47/10), the Minerva foundation with funding from the Federal German Ministry for Education and Research, a grant from the Chief Scientist Office at the Israeli Ministry of Health under the frame of ERA-Net NEURON (DISCover, IMOS 3-00000-6785), the Fritz-Thyseen Foundation (Grant Az. 10.11.2.161), the Benoziyo (enter for Neurological diseases, the Helen and Martin Kimmel Stem Cell Research Institute, and the David and Fela Shapell Family Center for Genetic Disorders Research. We thank Dr. llya Soifer for help with the analysis and Drs. Michael W. Davidson, Tamas Balla, and Masatoshi Hagiwara for providing us with useful plasmids.

The authors declare no competing financial interests.

Correspondence should be addressed to Orly Reiner, Department of Molecular Genetics, Weizmann Institute of Science, 76100 Rehovot, Israel. E-mail: orly.reiner@weizmann.ac.il.

DOI:10.1523/JNEUROSCI.5425-12.2013

Copyright $\odot 2013$ the authors $\quad 0270-6474 / 13 / 3311932-17 \$ 15.00 / 0$ down of several genes has been shown to inhibit or block this polarity acquisition. Nevertheless, the process of polarity acquisition in cortical neurons in the developing brain is not yet completely understood.

Analogies have been proposed between polarity regulation of cortical and hippocampal neurons (Watabe-Uchida et al., 2006; Arimura and Kaibuchi, 2007; Reiner and Sapir, 2009). One factor important for the latter is the protein Shootin1 (Toriyama et al., 2006, 2010, 2013; Shimada et al., 2008). Shootin1 protein accumulates in the growing axon during the transition between stages two and three, and its overexpression induces formation of multiple axons, whereas its knockdown inhibits polarization. Shootin 1 is also transported to the growth cone in actin-enriched structures (Toriyama et al., 2006). A subsequent study provided evidence for association of Shootin 1 with actin flow by demonstrating interaction between Shootin 1 and the neuronal cell adhesion molecule, L1CAM (Shimada et al., 2008). Recent studies indicated that within the growth cone, Shootin 1 is phosphorylated by Pak1, which resulted in increased interaction between Shootin 1 and F-actin retrograde flow, thereby promoting F-actin-substrate coupling, force generation, and concomitant filopodium extension and axon outgrowth (Toriyama et al., 2013).

We identified a member of the kinesin superfamily of proteins, KIF20B, as a novel Shootin1 interacting protein and mapped it to the KIF20B minimal binding domain (MBD). That peptide exhibited high-affinity binding to Shootin 1 and acted in a dominant-negative fashion. We found that Shootin1 and Kif20b are highly expressed in the developing mouse brain. Both 
proteins formed a complex in vivo and partially colocalized in primary neurons along microtubules. Following polymerization and depolymerization cycles of microtubules, Shootin 1 was detected in the microtubule-associated protein (MAP) fraction. In developing neurons, Shootin1 and Kif20b knockdown inhibited neuronal migration, and their combined knockdown did not exhibit an additive inhibitory effect, suggesting that they act in a common genetic pathway. Expression of the dominant-negative KIF20B MBD fragment also inhibited neuronal migration. Our results demonstrated that Shootin1 is a novel KIF20B cargo and that interaction with KIF20B localized Shootin1 to the tip of the growing axon. Importantly, reduction in either Shootin1 or KIF20B in multipolar neurons delayed their transition to bipolar neurons. Overall, our analysis indicates that KIF20B and Shootin 1 cooperate to regulate polarization of pyramidal neurons in the developing brain.

\section{Materials and Methods}

Plasmids. Full-length Shootin1 (FLCI-Shootin1, AK082304) was obtained from the Mouse Genome Encyclopedia Project of Genome Exploration Research Group in Riken. Three subclones of Shootin1 fragments (S1-S3) were generated in pGEM-Teasy and were used for further subcloning. pRsetB-Shootin1 (S1) was subcloned by BamHI/BglII-XhoI, pCAGG-GFP-Shootin1 (S1) was subcloned by NcoI and EcoRI with an adaptor, and pB27-Shootin1 (S1) and pGEX-4T1-Shootin1 (S1) were cloned by EcoRI and NcoI digestion.

mCherry-Shootin1 (S1) was cloned by SacII and SalI digestion. pRsetAShootin 1 (S2 and S3) was generated by BamHI/BglII and EcoRI digestion of the corresponding pGEM-Teasy plasmid. Mouse shRNA-Shootin248 (shRNA1) was cloned in pSuper using the following primers: 5 'GATCCC CCTGAAGCCTTGGCGACAAATTCAAGAGATTTGTCGCCAAGGCTT CAGTTTTTA and 5'AGCTTAAAAACTGAAGCCTTGGCGACAAATCT CTTGAATTTGTCGCCAAGGCTTCAGGGG.

Mouse shRNA-Shootin1 (shRNA2) was purchased from Open Biosystems TRCN0000071710. Full-length human Shootin1 was purchased from Open Biosystems, clone ID 5169981.

pGEM-Teasy-Shootin1 C-ter was cloned by PCR using the following primers:5' -AAGAGGCAAGCAGTGGAAGA, 5' -ACAGTTCCTGCCGG TTACAC and cloned into pGEM-Teasy digested by AgeI and SalI. pRsetA-Shootin1-C-ter was subcloned by NcoI and XhoI/SalI of the pGEM-Teasy plasmid. pCAGG-GFP-Shootin1-Cter was generated by digestion of NcoI/NotI and NheI of the pGEM-Teasy plasmid. pCAGGHuman-Shootin 1 used for rescue experiments was cloned by KpnI/XhoI and XbaI/NotI of the plasmid purchased from Open Biosystems.

Kif20b plasmids: Kif20b-A15, Kif20b-A7, Kif20b-A20, and Kif20b-A11 were obtained from the yeast two-hybrid screen. Kif20b-A20 was further used to produce Kif20b-MBD using PCR primers: 5'-GAGAATTCGAAA ATTCCTTCCAC, 5'-CTCTCGAGTTACTCCTGTGCTCGGAG, pGEX4T1-Kif20b-A7, pGEX-4T1-Kif20b-A20, pGEX-4T1-Kif20b-A11, and pGEX-4T1-Kif20b-A15 were cloned by EcoRI/NcoI-XhoI restriction digestion. pRsetA-Kif20b was cloned by BamHI and XhoI restriction digestion. Mouse shRNA-Kif20b plasmid was purchased from Open Biosystems, clone ID TRCN0000091234.

GFP-Kif20b-MBD was cloned by EcoRI and XhoI restriction digestion. pGEX-4T1-Kif20b-MBD single mutation (Y1047F) was generated by PCR (with an additional EcoRI site) using the following primers: 5' -GCGACCAT CCTCCAAAATC and 5'-GGCCGCTCGAGTTACTCCTGTGCTCGGAG GTCAGAATTCTCCTCCCTGAATCCTTTT. pGEX-4T1-Kif20b-MBD double mutation (Y1047F and R1048A) was generated by PCR using the single mutant plasmid as a template by PCR with the following primers: 5'-GCGACCATCCTCCAAAATCand 5'-GGCCGCTCGAGTTACTCCTG TGCTCGGAGGTCACTGTTCTCCTCCGCGAATCCTTTT. PI-(3,4,5)trisphosphate (PIP3) was visualized by green fluorescent protein (GFP)tagged pleckstrin homology $(\mathrm{PH})$ domain of PIP3 interacting protein, Akt (Várnai and Balla, 1998; received from Dr. Tamas Balla, National Institutes of Health, Bethesda, MD).
GFP-Kif20b-MBD-single mutation (Y1047F) was cloned by BamHI/ EcoRI and NotI digestion of the corresponding pGEX plasmid. pMEHA-tagged-human KIF20B was received from Masatoshi Hagiwara (Kamimoto et al., 2001).

Antibodies. Mouse monoclonal anti-glutathione S-transferase (GST) was purchased from University of California Davis (clone N100/13). Rabbit polyclonal anti-GST was purchased from Santa Cruz Biotechnology (SC-459 lot \#C0910). Mouse monoclonal anti-polyHistidine was purchased from Sigma (A5588). Mouse monoclonal anti-GFP was purchased from Roche (catalog \#11814460001). Rabbit polyclonal anti-GFP (serum) was produced against (B451) GFP protein. Rabbit polyclonal anti-Shootin 1 (S1; serum) was produced against pRSETB-Shootin1 (S1). Rabbit polyclonal anti-Shootin1 (C-ter; serum) was produced against pRSETA-Shootin1-C-ter. Rat polyclonal anti-Shootin1 (C-ter; serum) was produced against pRSETA-Shootin1-C-ter.

Rabbit polyclonal anti-Kif20b (serum) was produced against pRSETA-Kif20b-A20. Goat anti-MPP1 was purchased from Santa Cruz Biotechnology (SC-107002). Mouse monoclonal anti-tubulin DM1A was purchased from Sigma (T9026). Mouse monoclonal (hybridoma) anti-hemagglutinin (HA) antibodies were produced by the Weizmann Institute antibody unit. Goat anti-GFP biotinylated was purchased from Abcam (ab6658). The complete open-reading frame of mouse Shootin1 (GenBank accession number gi: 146198590) or the C-terminal region (amino acid residues 413-630) was reverse transcribed from embryonic brain mouse RNA, amplified using PCR, cloned into the pRSET vector (Invitrogen), and the sequence was verified. The Shootin1 protein (S1) (pRSET-Shootin1) was purified using a nickel-agarose column according to the manufacturer's protocol (Qiagen). Antisera to recombinant Shootin1 or Shootin1 C-ter were generated in rabbits and/or rats. Antibodies were verified using Western blot analysis; specificity for immunostaining was tested using pre-incubation with the injected antigen as previously described (Kaplan and Reiner, 2011).

GST-tagged protein purification. GST-fusion plasmids, representing different Kif20b fragments, were transfected into BL21(DE3)RIL bacteria (Stratagene), which were grown in Luria-Bertani at $30^{\circ} \mathrm{C}$ to an optical density of $0.7-0.8$. Induction of protein expression was performed using $0.2 \mathrm{~mm}$ IPTG for $4 \mathrm{~h}$. Protein was extracted in NETN buffer $(0.5 \%$ Nonidet P-40, $0.1 \mathrm{~m} \mathrm{NaCl}, 1 \mathrm{~mm}$ EDTA, $20 \mathrm{~mm}$ Tris- $\mathrm{HCl}, \mathrm{pH}$ 8.0) with sonication. The soluble fraction was bound to glutathione agarose beads (Sigma) for $1 \mathrm{~h}$, cleared by centrifugation above $20 \%$ sucrose-NETN, and washed extensively in NETN buffer before elution from column in $50 \mathrm{~mm}$ Tris- $\mathrm{HCl}, \mathrm{pH} 8.0,0.15 \mathrm{M} \mathrm{NaCl}, 10 \mathrm{~mm}$ glutathione, and $10 \%$ glycerol.

GST pull-down assay. Recombinant proteins $(6 \times$ His-tagged Shootin 1 proteins) were incubated with $10 \mathrm{Al}$ of GST-tagged proteins at $4^{\circ} \mathrm{C}$ for $3 \mathrm{~h}$. Glutathione beads (10 $\mathrm{ml}$ bed volume) preblocked in T-T buffer supplemented with $10 \mathrm{mg} / \mathrm{ml}$ bovine serum albumin (BSA) (Sigma) were added to the protein mixture and rotated for $30 \mathrm{~min}$ at room temperature (RT); after four washes with T-T buffer, $2 \times$ sample buffer was added, and the beads were boiled and proteins were separated by SDS-PAGE and Western blot analysis.

Immunoprecipitation. Immunoprecipitation was performed from ICR mice (E14) brain extracts prepared in IP buffer (50 mM Tris, pH 7.5, 150 $\mathrm{mm} \mathrm{NaCl}, 1 \%$ Triton X-100) supplemented with protease inhibitors (Sigma). Brain extract $(500 \mu \mathrm{g})$ was incubated with indicated antibodies for $2 \mathrm{~h}$ at $4^{\circ} \mathrm{C}$. Following this, $10 \mathrm{ml}$ (bed volume) of protein A/G agarose (Santa Cruz Biotechnology) preblocked in IP buffer supplemented with $10 \mathrm{mg} / \mathrm{ml} \mathrm{BSA} \mathrm{(Sigma)} \mathrm{was} \mathrm{added} \mathrm{to} \mathrm{each} \mathrm{sample} \mathrm{for} \mathrm{additional} 2 \mathrm{~h}$. Immunoprecipitated proteins were pelleted by centrifugation, washed three times with IP buffer, eluted by addition of SDS-PAGE sample buffer, boiled for $2 \mathrm{~min}$, and analyzed by SDS-PAGE.

Microtubule cosedimentation assay. Bovine brain tubulin obtained from freshly slaughtered calves was purified through two cycles of polymerization-depolymerization, followed by chromatography on a phosphocellulose column and a third cycle of polymerization-depolymerization, as described previously (Williams, 1992; Fygenson et al., 1994). Both recombinant proteins and tubulin were centrifuged at $100,000 \mathrm{~g}$ for $30 \mathrm{~min}$ to remove protein aggregates. Tubulin was incubated with PEM buffer ( $80 \mathrm{~mm}$ PIPES. $\mathrm{pH}$ 6.9, $1 \mathrm{~mm} \mathrm{MgCl}_{2}, 1 \mathrm{~mm}$ 
EGTA), $1 \mathrm{~mm}$ GTP, and $10 \%$ glycerol at $35^{\circ} \mathrm{C}$ for $15 \mathrm{~min}$. Taxol or nocodazole were added to the mixture for $15 \mathrm{~min}$ at RT or on ice, then the recombinant proteins (histidine tagged-Shootinl or GST as negative control), diluted in PEM buffer, were added to the mixture for additional incubation of $30 \mathrm{~min}$ at RT. The reaction was carefully laid over $125 \mathrm{ml}$ of cushion buffer (50\% glycerol in PEM buffer) and centrifuged at 100,000 $g$ for $1 \mathrm{~h}$. Samples of the supernatant were collected and the pellet was washed with PEM buffer and then diluted with concentrated protein sample buffer. The results were analyzed on a 10\% SDS PAGE gel followed by Western blotting.

Immunohistochemistry. Antibodies were used to stain primary neuronal cultures and brain sections. Floating sections or coverslips containing fixed cells were blocked in blocking solution [PBS, 0.1\% Triton X-100, $10 \% \mathrm{HS}, 10 \%$ fetal calf serum (FCS)] for $30 \mathrm{~min}$. Antibodies were incubated in blocking solution overnight at $4^{\circ} \mathrm{C}$. After washing, appropriate secondary antibodies (Jackson ImmunoResearch) were diluted in blocking solution, and incubated for $30 \mathrm{~min}$ at room temperature. Slices were mounted onto glass slides using Aqua Poly/mount (Polyscience). Dual immunostaining was performed on primary cortical and hippocampal neurons, which were fixed by immersion in $4 \%$ paraformaldehyde (PFA)-PBS for $20 \mathrm{~min}$ and then washed three times. The slides were permeabilized for 10 min using PBS containing $0.1 \%$ Triton X-100 (PBS/ $0.1 \% \mathrm{TX})$. The slides were blocked with $10 \%$ normal horse serum in PBS/0.1\% TX for $30 \mathrm{~min}$. Following blocking the slides were incubated overnight in the first rabbit antibody solution. This incubation was followed by three washes in PBS/0.1\%TX and a longer incubation (10 min) in PBS. The slides were then incubated in FITC-AffiniPure Fab Fragment Goat Anti-Rabbit IgG (Jackson ImmunoResearch) diluted 1:50 in PBS/ $0.1 \% \mathrm{TX}$, for $2 \mathrm{~h}$ at RT. This incubation was followed by five $5 \mathrm{~min}$ washes in PBS/0.1\% TX followed by a 60 min wash in PBS, then the slides were blocked overnight with a nonconjugated AffiniPure Fab Fragment Goat Anti-Rabbit IgG $(\mathrm{H}+\mathrm{L})$ diluted 1:10 in PBS/0.1\%TX. Later the slides were washed as previously and incubated with the second rabbit primary antibody at $4^{\circ} \mathrm{C}$, overnight. The second primary was thoroughly washed and the slides were incubated in a secondary antibody, Cy3-AffiniPure Donkey Anti-Rabbit IgG $(\mathrm{H}+\mathrm{L})$, for $3 \mathrm{~h}$ at room temperature. As a precaution, reversal of the order of introduction of the two primary antibodies was performed as well as single immunostaining in which each of the primary rabbit antibodies was used separately.

Yeast two-hybrid analysis. Yeast two-hybrid screening was performed by Hybrigenics Services, SAS (http://www.hybrigenics-services.com). The coding sequence for Shootinl (GenBank accession number gi: 146198590) was PCR amplified and cloned into pB27 as a C-terminal fusion to LexA (N-LexA-SHOOTIN-C). The construct was checked by sequencing the entire insert and used as a bait to screen a random-primed mouse embryo brain cDNA library constructed into pP6. pB27 and pP6 derive from the original pBTM116 (Vojtek and Hollenberg, 1995) and pGADGH (Bartel et al., 1993) plasmids, respectively.

Then 130 million clones (17-fold the complexity of the library) were screened using a mating approach with Y187 (mat) and L40Gal4 (mata) yeast strains as previously described (Fromont-Racine et al., 1997). Twenty-eight histidine-positive colonies were selected on a medium lacking tryptophan, leucine, and histidine. The prey fragments of the positive clones were amplified by PCR and sequenced at their $5^{\prime}$ and $3^{\prime}$ junctions. The resulting sequences were used to identify the corresponding interacting proteins in the GenBank database (NCBI) using a fully automated procedure. A confidence score (PBS, for Predicted Biological Score) was attributed to each interaction as previously described (Formstecher et al., 2005).

Further description of the confidence score. The PBS relies on two different levels of analysis. First, a local score takes into account the redundancy and independency of prey fragments, as well as the distribution of reading frames and stop codons in overlapping fragments. Second, a global score takes into account the interactions found in all the screens performed at Hybrigenics using the same library. This global score represents the probability of an interaction being nonspecific. For practical use, the scores were divided into four categories, from A (highest confidence) to D (lowest confidence). A fifth category (E) specifically flags interactions involving highly connected prey domains previously found several times in screens performed on libraries derived from the same organism. Finally, several of these highly connected domains have been confirmed as false positives of the technique and are now tagged as F. The PBS scores have been shown to positively correlate with the biological significance of interactions (Rain et al., 2001; Wojcik et al., 2002).

Biacore analysis. SPR was performed on a Biacore 3000 instrument (Biacore), using a CM-5 BIAcore sensor chip (GE Healthcare BioSciences AB). Kif20b was diluted in $100 \mathrm{~mm} \mathrm{CH} 3 \mathrm{COONa}$, pH 4.6, to a final concentration of $20 \mu \mathrm{g} / \mathrm{ml}$, in a total volume of $200 \mu \mathrm{l}$ and coupled using the standard Biacore amine chemistry protocol. The analyte, Shootin1 (S1), was injected in the running buffer (PBS) at different concentrations at a flow rate of $20 \mu \mathrm{l} / \mathrm{min}$ at $25^{\circ} \mathrm{C}$. These conditions resulted in a linear relation between the protein concentration and the maximal (steady-state) response, indicating the pseudo first-order regime in relation to the immobilized ligand. Injections were performed simultaneously over all four channels and blank surface a plain dextran matrix (channel 1) was used as control. The net signal was obtained by subtracting the blank signal from the signal of the immobilized surface. The association phase for Shootin 1 binding to Kif20b was followed for $4 \mathrm{~min}$, and the dissociation phases were monitored for $3 \mathrm{~min}$. Surface regeneration between consecutive binding cycles included a $1 \mathrm{~min}$ injection of 2 $\mathrm{mm} \mathrm{NaOH}$. The response was monitored as a function of time (sensorgram) at $25^{\circ} \mathrm{C}$. Multiconcentration data were globally fit using BIAevaluation 3.2 software.

In utero electroporation. In utero electroporation was conducted as previously described (Sapir et al., 2008a). Four days after electroporation (unless otherwise stated), E18 embryos of either sex were intracardially perfused using 4\% PFA-PBS, the brains were postfixed overnight and sectioned. Alternatively, pups were anesthetized and perfused postnatally (P8). The location of treated cells was analyzed in sections by measuring the signal detected in eight bins spanning the width of the cortex from at least four different brains per treatment, and the relative percentage of the signal was compared by ANOVA (Prism 4 for Macintosh; GraphPad Software). Pictures were taken from $60-\mu \mathrm{m}$-thick vibratome sections using Zeiss Confocal or Applied Precision DeltaVision microscopy. shRNA constructs including Shootin1 shRNA sequences are pLKO.1. Lentiviral shRNA constructs were purchased form Open BioSystems. Routinely two control shRNAs were used: a pSUPER-based control previously described (Sapir et al., 2008a) and a pLKO.1-TRC (Addgene) control shRNA. The shRNA constructs were coelectroporated with either pCAGGS-GFP or Golgi localization sequence fused to dsRed (a gift from Michael Davidson, Florida). Animal protocols were approved by the Weizmann Institute Institutional Animal Care and Use Committee.

Neuronal cultures. Cultures were prepared as detailed previously (Goldin et al., 2001). Briefly, mouse embryos (E18) were decapitated and their brains were removed and placed in a chilled $\left(4^{\circ} \mathrm{C}\right)$, oxygenated Leibovitz L-15 medium (Invitrogen) enriched with $0.6 \%$ glucose and gentamicin (20 $\mu \mathrm{g} / \mathrm{ml}$; Sigma). Hippocampal or cortical tissue was mechanically dissociated and passed to the plating medium consisting of 5\% heatinactivated horse serum, 5\% FCS, and B-27 supplement prepared in minimum essential medium (MEM) Earl salts (Invitrogen), enriched with $0.6 \%$ glucose, gentamicin $(20 \mu \mathrm{g} / \mathrm{ml})$, and $2 \mathrm{~mm}$ glutamax (enriched MEM). Approximately $0.5 \times 10^{6}$ cells were plated in each well of a 24 well plate containing poly-L-lysine/laminin-coated coverslips. Electroporations were done using the NEPA21 electroporation system (Nepa Gene). Adherent cells were electroporated $1 \mathrm{~d}$ after plating using CUY900 electrode while suspended cells were electroporated using a cuvette according to the manufacturer recommendations.

Live imaging. Electroporated brains were harvested 2-3 d after electroporation (E16-E17). Brains were excised in ice-cold L-15 media supplemented with glucose $(0.6 \%)$, gentamicin $(0.02 \mathrm{mg} / \mathrm{ml})$, and oxygen. Brains were embedded in 3.5\% low-melt agarose dissolved in L-15 and cut to $300-\mu \mathrm{m}$-thick slices by a vibratome. The explants were placed onto Millicell-CM inserts floating on Neurobasal medium supplemented with B27 and N2, 2 mm GlutaMax, 0.5\% glucose, and gentamicin. Images were taken $2 \mathrm{~h}$ after plating in Applied Precision DeltaVision microscopy equipped with an environmental chamber.

Sparse cell labeling was done as previously described (Matsuda and Cepko, 2007; Morin et al., 2007; Konno et al., 2008) by using pT $\alpha$-LPL 
(loxP-polyA-loxP) plasmid containing a poly-adenylation signal flanked by two loxP sites between the T $\alpha 1$ promoter (Gloster et al., 1999) and the open reading frame. Briefly, shRNA vector, together with the pT $\alpha$-LPLLynN-EGFP (MGCIKSKRKD-EGFP; Lyn N-terminal membranetargeted signal-fused EGFP), and $\mathrm{pT} \alpha$-Cre, were electroporated in utero at E12, and slices were prepared $2 \mathrm{~d}$ later. The slices were embedded in a glass-bottom $35 \mathrm{~mm}$ culture dish with collagen gel and slice culture was performed as described previously (Miyata et al., 2001). The slices were kept at $37^{\circ} \mathrm{C}$ in an ONICS humidified incubator chamber (Tokai Hit) on the stage of microscope, with a continuous supply of $45 \% \mathrm{O}_{2} / 5 \% \mathrm{CO}_{2} /$ $50 \% \mathrm{~N} 2$ gas. Cross-section images through the glass bottom were acquired with a $40 \times / 0.75$ UPLFLN objective lens (Olympus) using a FV-1000 confocal laser scanning microscope system (Olympus). Fluorescence recovery after photobleaching (FRAP) was performed on a Zeiss 510 META confocal microscope. The imaged cultures were maintained at $37^{\circ} \mathrm{C}$ with the addition of $5 \% \mathrm{CO}_{2}$.

\section{Results}

\section{Shootin1 interacts with Kif20b}

Cell polarization requires the organization of protein complexes in specific subcellular compartments, therefore we hypothesized that Shootin 1 works with an additional unknown partner(s). Potential interaction partners were identified by a yeast two-hybrid screen of a mouse embryonic brain cDNA library. Following screening of 130 million clones (17-fold the complexity of the library), 18 high confidence score clones were identified, all representing overlapping or identical fragments of the kinesin superfamily protein Kif20b (schematic presentation of Kif20b and representative clones resulting from the yeast two-hybrid screen are shown in Fig. 1A). Based on these results, we constructed an MBD of 57 aa (amino acid residues 1002-1059), defined by a region common to all positive clones (Fig. $1 A$ ). The mapping of interaction domains was facilitated by the generation of C-terminal truncations of Shootin1 (Fig. 1B). Shootin1/Kif20b interaction was verified and mapped using GST pull-down experiments (Fig. 1C). Shootin 1 proteins (S1, 1-456; S2, 1-257; and S3, 1-189) were expressed and purified from bacteria as sixhistidine fusion proteins, whereas Kif20b fragments (MBD, amino acid residues 1002-1059; A20, amino acid residues 10021442; A7, amino acid residues 867-1270) were expressed and purified from bacteria as GST-fusion proteins. Overall, we determined that the first 189 aa of Shootin 1 were sufficient to bind all Kif20b fragments tested, whereas the Kif20b MBD was sufficient for Shootin1 association (Fig. 1C).

To determine whether the two proteins form a complex in vivo, we undertook immunoprecipitation of HEK293 cells transfected with Shootin1 (Fig. 1D,E). Anti-Kif20b antibodies immunoprecipitated Shootin1, as well as Kif20b itself (Fig. 1D,E). Reciprocally, anti-Shootin1 antibodies immunoprecipitated Kif20b, as well as Shootin1 (Fig. 1D,E). No immunoprecipitated Kif20b or Shootin1 were detected in the absence of specific antibodies (Fig. $1 D, E$ ). Immunoprecipitation of brain extracts revealed that two different Shootin1 antibodies immunoprecipitated Kif20b (Fig. 1F), and these two antibodies immunoprecipitated Shootin1 protein (Fig. $1 G$ ). Anti-Kif20b antibodies immunoprecipitated endogenous Shootin1 protein and were able to self-immunoprecipitate Kif20b (Fig. $1 F)$.

To further define Shootin1/Kif20b interaction we used the Biacore, a system that measures changes in surface plasmon resonance, which are proportional to the changes in the mass of molecular species bound to the surface (Fägerstam et al., 1992; Jonsson and Malmqvist, 1992; Malmqvist, 1993; Raghavan and Bjorkman, 1995). The Kif20b MBD fragment was immobilized to a sensor chip and the binding of increasing concentrations of recombinant Shootin 1 (S1) in the flow through was monitored (Fig. $1 H$ ). The equilibrium dissociation (KD) calculated from experimental curves was found to be $1.75 \mathrm{E}^{-07} \mathrm{M}$. Overall, these analyses indicate that Kif20b and Shootin1 directly interact. Close inspection of the Kif20b MBD amino acid sequence did not reveal any consensus motifs, which may mediate protein interactions. Yet, since tyrosine residues are known to mediate multiple protein interactions such as sorting signals (Ohno et al., 1995, 1996), we mutated the single tyrosine in that region (Y1047) to phenylalanine $(\mathrm{F})$ and along with an adjacent charged residue (R1048 to A). BIAcore analysis revealed that Kif20b MBD interaction with Shootin 1 was reduced following mutation of tyrosine only and the double mutation significantly reduced the interaction (Fig. 1I). We then asked whether the Kif20b MBD might interfere with binding of Shootin1 to Kif20b. Addition of the wild-type Kif20b MBD to soluble Shootin1 prevented Shootin1 binding to the surface (Fig. $1 \mathrm{~J}$ ). However, addition of the doubly mutant Y1047F/R1048A MBD did not have this effect (Fig. 1K). These results indicate that Shootin1 binds Kif20b through the $\mathrm{MBD}$ and that binding is dependent on YR residues found at positions 1047/1048.

Kif20b functions have been previously characterized in dividing tissue culture cells, where it was identified as a phosphorylated microtubule associated plus-end-directed molecular motor protein, which is required for proper completion of mitosis (Matsumoto-Taniura et al., 1996; Kamimoto et al., 2001; Abaza et al., 2003). Interestingly, immunostaining of Shootin 1 in interphase (Fig. 2A-C) and mitotic HeLa cells (Fig. $2 D-F$ ) revealed partial colocalization of Shootin 1 with microtubules. Our results confirmed the previously reported immunostaining of Kif20b as punctate dots along interphase microtubules (Fig. 2G-I) and in the midbody (Fig. 2J-L). The partial colocalization of Shootin 1 with microtubules promoted us to investigate whether Shootin 1 can be detected in the brain MAP fraction. First, we tested the expression of Shootin 1 in the developing brain. Immunoblotting detected expression of Shootin1 in cell lysates prepared from mouse cortices: a high molecular weight $(\sim 72 \mathrm{kDa})$ form of Shootin1 was expressed at low levels at E11, while at later time points (E13, E15, E18, and P2) both lower $(\sim 53 \mathrm{kDa})$ and higher molecular weight forms were highly expressed (Fig. 2M). These molecular weights correspond to the predicted protein products of long and short splice forms reported in UniProtKB/Swiss-Prot entry Q8K2Q9. Both Shootin1 isoforms were highly enriched in the MAP fraction following cycles of tubulin polymerization and depolymerization and elution from a column using high salt concentration (Fig. 2M). To investigate a potential interaction between Shootin 1 and microtubules we performed a cosedimentation assay (Fig. 2N). Purified tubulin was polymerized with the recombinant short isoform of Shootin 1 protein in the presence of either the microtubule-stabilizing drug taxol or the microtubule-destabilizing drug nocodazole. The assay relies on the fact that proteins that bind to polymerized microtubules will cosediment through a glycerol-rich cushion following highspeed centrifugation. Following the addition of taxol, the majority of Shootin 1 was found in the supernatant and did not cosediment with microtubules, thus suggesting an indirect interaction between Shootin 1 and microtubules. The addition of nocodazole reduced the amount of tubulin and Shootin 1 proteins detected in the pellet (Fig. 2N). However, the addition of brainpurified MAPs resulted in more Shootin1 detected in the taxol pellet fraction (Fig. $2 N$ ), thus suggesting that a $\operatorname{MAP}(\mathrm{s})$ is mediating the interaction of Shootin 1 and microtubules. We tested whether Kif20b, which is known to bind microtubules directly 
A Kif20b
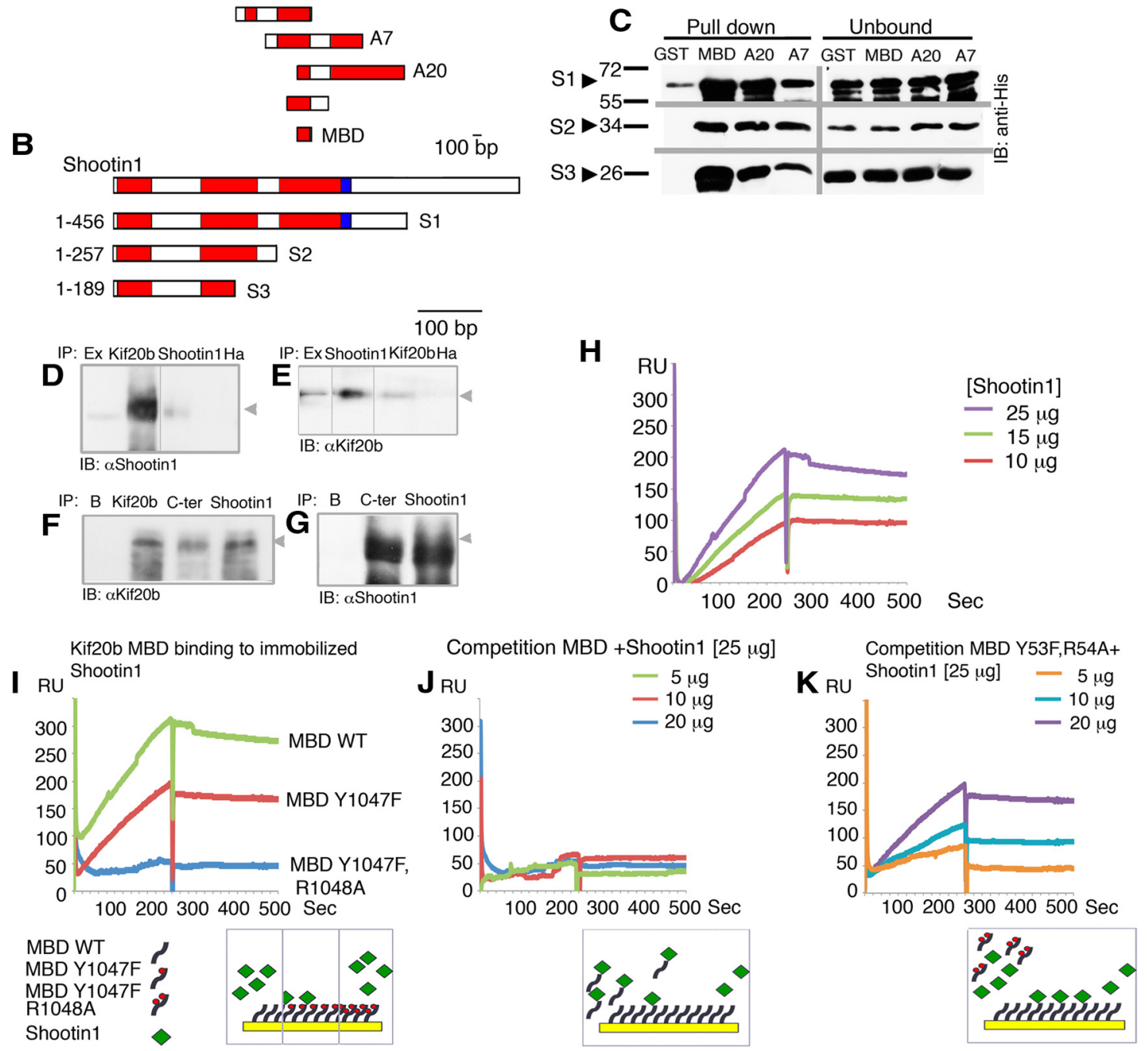

Figure 1. Shootin1 and Kif20b interaction. A, Schematic presentation of Kif20b and four fragments, which were identified in a yeast two-hybrid screen as interacting with Shootin1. Kif20b-A7 and Kif20b-A20 were further studied biochemically. Kif20b MBD is the minimal common domain to all Kif20b clones found to interact with Shootin1. The motor domain is highlighted in green, and coiled-coil domains are indicated in red. B, Shootin1 long splice form and a series of C-terminal truncations. S1, Shootin 1 short splice form; S2, S3, truncated Shootin1; red, predicted coiled coil domain; blue, proline rich domain. C, Pull down of the recombinant Shootin 1 short splice form (S1) and C-terminal truncations (S2,S3) by recombinant GST-fusion Kif20b fragments (Kif20b-A7, Kif20b-A20, and MBD). IB, immunoblot. Immunoprecipitation from Shootin1-transfected HEK 293 (D, E) and from E14.5 embryonic brain lysates $(\boldsymbol{F}, \mathbf{G})$. IP, immunoprecipitation; Ex, cell extract; B, beads only control, Ha, control antibodies (anti-HA tag antibodies); (-ter, polyclonal anti-Shootin1 antibodies raised against a C-terminal fragment; Kif20b, polyclonal anti-Kif20b antibodies. $\boldsymbol{H}$, Surface plasmon resonance (Biacore), measurements of the binding of soluble recombinant Shootin $1 \mathrm{~S} 1$, (analyte) to immobilized MBD of Kif2Ob (ligand). I- $\boldsymbol{K}$, Surface plasmon resonance (Biacore), measurements of the binding of soluble recombinant Shootin1 S1, (analyte) to immobilized wild-type or mutated MBD of Kif20b (ligand). I, Shootin 1 bound to wild-type (WT) Kif20b MBD, less Kif20b MBD carrying a single mutation (MBD Y1047F), and very low binding to the doubly mutant Kif20b MBD fragment (MBD Y1047F, R1048A). J, Pre-incubation of different concentrations of Kif20b MBD with Shootin1 inhibits binding to the immobilized Kif20b MBD. $\boldsymbol{K}$, Preincubation of low concentration of doubly mutant MBD does not prevent the binding of Shootin1 to the same surface; however, increased concentrations partially inhibit the binding.

(Abaza et al., 2003), is also detected in the MAP fraction. In bovine MAP fractions, we can detect both Shootin1 and Kif20b (Fig. 2O). We suggest that Kif20b may be mediating the interaction between Shootin 1 and microtubules.

\section{Shootin 1 and Kif20b are expressed in the developing brain}

To investigate potential functions for Shootin 1 and Kif20b in cortical neurogenesis, we asked whether they are expressed in the developing mouse telencephalon. In situ hybridization indicated that Shootin1 mRNA expression was highest in the developing cortical plate (Fig. $2 P-R$ ). Shootin 1 antibodies also revealed strong immunostaining in the developing cortical plate at E11 and E14 (Fig. 2S,T, respectively). We used anti-Kif20b antibodies we generated as well as commercially available ones (goat antiMPP1), to immunostain brain slices of E14.5 embryos. Similar expression patterns were noted using both antibodies (Fig. $2 U-\mathrm{V}$ vs $X, Y)$. Kif20b was detected in the apical aspect of the ventricular zone, in the marginal zone, in a narrow stripe between the intermediate zone and the cortical plate, and in somewhat lower levels in the cortical plate. Interestingly, midbodies were notable in the ventricular zone, recapitulating our observation in HeLa cells (Fig. $2 G-L, Y-A A$ ). To gain information regarding intracellular protein localization during the polarization of cortical neurons, we prepared slices from E14.5 brains that were coelectroporated $2 \mathrm{~d}$ earlier with a plasmid carrying Cre, and with a Cre-activated membranal GFP. The labeling of single cells al- 

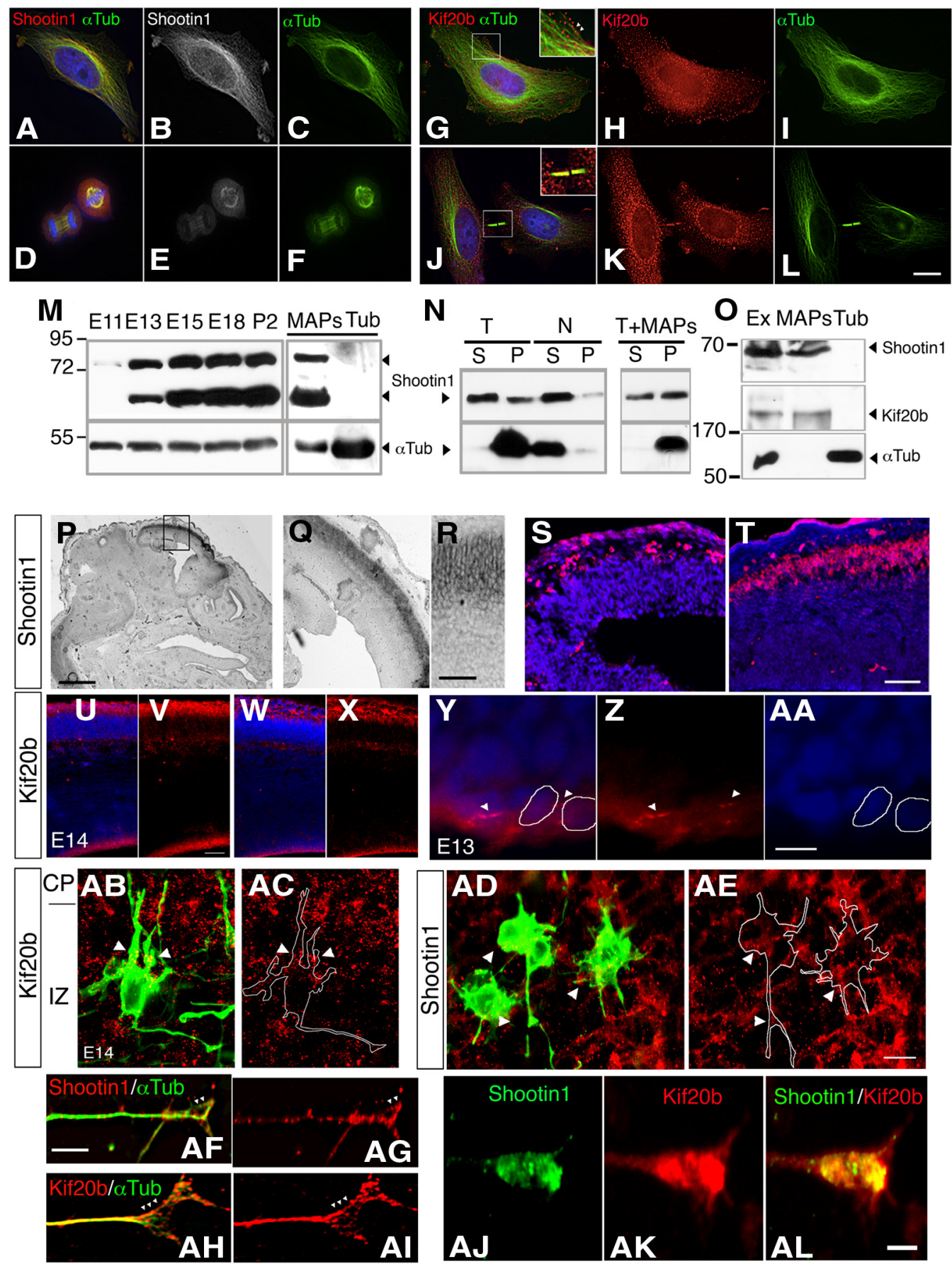

Figure 2. The expression pattern of Shootin1 and Kif20b. $\boldsymbol{A}-\boldsymbol{L}$, HeLa cells immunostained with anti-Shootin1 antibodies $(\boldsymbol{A}-\boldsymbol{F})$ and anti-Kif20b antibodies $(\mathbf{G}-\boldsymbol{L})$. Immunostainings are showing Shootin 1 (red in $\boldsymbol{A}$ and $\boldsymbol{D}$ and white in $\boldsymbol{B}-\boldsymbol{E}$ ), $\alpha$-Tubulin, (green in $\boldsymbol{C}, \boldsymbol{F}, \boldsymbol{G}, \boldsymbol{J}, \boldsymbol{I}$, and $\boldsymbol{L}$ ), DAPI (blue in $\boldsymbol{A}, \boldsymbol{D}$ ), and Kif20b (red in $\boldsymbol{G}, \boldsymbol{H}, \boldsymbol{J}$, and $\boldsymbol{K}$ ). $\boldsymbol{M}$, Expression of Shootin1 in embryonic brain lysates. Shootin1 is enriched in the MAPs fraction of early postnatal brain extracts but not in the tubulin (Tub)-enriched fraction. $\boldsymbol{N}$, Cosedimentation assay of microtubules polymerized with taxol (T) or depolymerized with nocodazole (N), and Shootin1 appears to be enriched in the supernatant (S). Addition of MAPs allows a higher proportion of Shootin1 to cosediment with the taxol-stabilized microtubules pellet (P). $\mathbf{0}$, Shootin1 and Kif20b copurify with MAPs from bovine brain extract. Ex, extract; Tub, tubulin fraction. $\boldsymbol{P}-\boldsymbol{R}$, Shootin1 $\mathrm{mRNA}$ expression is detected in the cortical plate of E15.5 embryonic brain by in situ hybridization. $\boldsymbol{S}, \boldsymbol{T}$, Shootin 1 protein expression in the cortex detected by immunohistochemistry of E11.5 $(\boldsymbol{S})$ and E14.5 $(\boldsymbol{T})$ coronal cortical sections using polyclonal anti-Shootin1 antibodies (Shootin1, red; DAPI, blue). $\boldsymbol{U}-\boldsymbol{A} \boldsymbol{A}$, Kif20b expression in the developing brain. Anti-Kif20b antibodies $(\boldsymbol{U}-\boldsymbol{V})$ or anti-MPP1 $(\boldsymbol{W}, \boldsymbol{X})$ detect Kif20b in the apical aspect of the ventricular zone, in the marginal zone, and in a narrow stripe between the intermediate zone and the cortical plate and in lower levels in the cortical plate. $Y$-AA, Anti-Kif2Ob antibodies immunostain midbodies between dividing radial progenitors in the ventricular zone (Kif20b, red; DAPI, blue). $\boldsymbol{A B}$ - $\boldsymbol{A E}$, Sporadic labeling (Cre-activated Lyn-GFP; green) of multipolar cells in slices prepared from E14 mice embryos brains (electroporated at E12.5). Multipolar cells are expressing both Kif20b ( $\boldsymbol{A} \boldsymbol{B}$ and $\boldsymbol{A C}$, red) and Shootin 1 ( $\boldsymbol{A D}$ and $\boldsymbol{A E}$; red). $\boldsymbol{A F}-\boldsymbol{A I}$, Partial colocalization of Shootin 1 ( $\boldsymbol{A F}$ and $\boldsymbol{A G}$, red) and Kif20b ( $\boldsymbol{A H}$ and $\boldsymbol{A l}$, red) with microtubules (green) in the shaft of the growth cone in primary hippocampal neurons. Both proteins appear as dots that decorate the microtubules (white arrowheads). $\boldsymbol{A} \boldsymbol{J}-\boldsymbol{A} \boldsymbol{L}$, Partial colocalization ( $\boldsymbol{A} \boldsymbol{L}$, yellow) of Shootin 1 ( $\boldsymbol{A} \boldsymbol{J}$ and $\boldsymbol{A L}$, green) and Kif20b ( $\boldsymbol{A} \boldsymbol{K}$ and $\boldsymbol{A L}$, red) in hippocampal neuron growth cone (AI-AL). Scale bars: $\boldsymbol{L}, 50 \mu \mathrm{m} ; \boldsymbol{P}, 1 \mathrm{~mm} ; \boldsymbol{R}$, $50 \mu \mathrm{m} ; T, 50 \mu \mathrm{m} ; A A, 10 \mu \mathrm{m} ; A E, 10 \mu \mathrm{m} ; A L, 2 \mu \mathrm{m}$. 
lowed us to locate cells exhibiting multipolar morphology (Fig. $2 A B-A E)$. We noted that in these cells both Kif20b and Shootin 1 appeared in dots that were distributed in perinuclear positions. Kif20b was detected in the processes of the multipolar cells with some bias to those pointing toward the pial surface. Shootin 1 was detected in multiple processes of the multipolar cells as well in the extending axon. Additionally, we used the same antibodies to stain cultured primary hippocampal neurons, costaining with DMIA (anti- $\alpha$-tubulin) revealed puncta decorating the microtubules within the growth cones (Fig. $2 A F, A H$ ). Furthermore, coimmunostaining of Shootin 1 and Kif20b revealed partial colocalization within growth cones of primary hippocampal neurons (Fig. 2AJ-AL). These expression patterns suggest partial colocalization of the two proteins during cortical development, in multipolar cells and in the growth cones of primary hippocampal neurons.

\section{KIF20B mobilizes Shootin1 to the growth cone}

KIF20B belongs to the kinesin superfamily of proteins, which includes many microtubule-associated molecular motors. KIF20B has a motor domain in its $\mathrm{N}$-terminal region and thus belongs to the $\mathrm{N}$-kinesins that are known to drive microtubule plus-end-directed motility (for review, see Hirokawa et al., 2009). We postulated that Shootin1 might be a KIF20B cargo. In pyramidal hippocampal neurons transfected with Shootin1mCherry, we observed Shootin 1 in the cell soma and in the growth cone (Fig. 3A- $B^{\prime}$ ). However, when Kif20b was knocked down Shootin1-containing puncta were detected along the axon (Fig. $3 C-D^{\prime}$ ), thus, suggesting a transport defect in these neurons. To gain further insight into the dynamics of Shootin1/KIF20B interaction we conducted FRAP analysis. Primary hippocampal neurons were cotransfected with Shootin1-GFP and either control or Kif20b shRNA or were treated with nocodazole; fluorescence was bleached in the entire growth cone and recovery of GFP intensity was monitored over time. The time of recovery was significantly reduced in the presence of Kif20b shRNA or following treatment with nocodazole (Fig. $3 E$ ). The efficiency of nocodazole treatment was verified by immunostaining with antitubulin antibodies (data not shown). The time of recovery to a level of $40 \%$ of the initial fluorescence signal was more than doubled (control shRNA T40 $=30.6 \pm 9.8$ vs Kif20b shRNA T40 $=$ $74.1 \pm 33$, nocodazole T40 $=74.2 \pm 20, n=11$ ). Representative images of two cells demonstrate visible differences in the fluorescence intensity between the two treatments (Fig. $3 F-H$ vs $I-K$ ). Therefore, we concluded that KIF20B participates in mobilizing Shootin 1 to the growth cone. Furthermore, the effect of nocodazole implies that intact microtubules are required for this mobilization as well as intact actin following treatment with blebbistatin (data not shown, and as previously reported; Toriyama et al., 2006). We postulated that expression of the Kif20b MBD within neurons may interfere with proper mobilization of Shootin1 in the axon. Indeed, live imaging revealed more mCherry-Shootin1 along the axon when Kif20b MBD-GFP was expressed in comparison with GFP or doubly mutated Kif20b MBD (Fig. $3 L, M$ ).

Shootin1 knockdown was previously shown to reduce localized activity of PI 3-kinase in growth cones of primary hippocampal neurons (Toriyama et al., 2006). We assessed localization of the product of PI 3-kinase activity, PIP3, using the PH domain construct of Akt (Akt-PH-GFP), which specifically interacts with PIP3 in cells, thus acting as a PIP3 sensor (Várnai and Balla, 1998). Our results in primary hippocampal neurons transfected with Shootin 1 shRNA confirmed previous findings (Fig. $3 N$ ).
Kif20b knockdown resulted in less accumulation of the PIP3 sensor in neuronal growth cones (Fig. $3 \mathrm{~N}$ ). Figure 30 shows the plots of average intensity distribution of multiple analyzed cells ( $n=30,35,29$ for control, Shootin1 shRNA, or Kif20b shRNA, respectively). Calculation of correlation coefficients between the intensity and the relative position in the axon indicated greater similarity between Shootin 1 and Kif20b shRNA treatments $\left(r^{2}=\right.$ $0.45)$ than between control and Shootin 1 treatment $\left(r^{2}=0.08\right)$ or than between control and Kif20b shRNA treatment $\left(r^{2}=\right.$ 0.16). Statistical analysis using ANOVA and Dunnett's multiplecomparison test revealed that the intensity and the relative position in the axon seen following Kif20b shRNA treatment differed significantly from control $(p<0.05)$. Collectively, our experiments suggest that Shootin1 is a novel KIF20B cargo and that both proteins promote PIP3 accumulation in the growth cone.

\section{Shootin1 and/or Kif20b knockdown inhibit neuronal migration}

To further evaluate how Shootin1 and Kif20b may regulate brain development, we acutely transfected combinations of Shootin 1 , Kif20b, and control shRNAs into the developing mouse brain using in utero electroporation (Fig. 4). Four days after their in utero electroporation, Shootin 1 knockdown significantly reduced the proportion of neurons reaching the cortical plate in comparison with control shRNA (Fig. $4 B$ vs $A$ ). Shootin 1 shRNA specificity was demonstrated by rescue of neuronal migration following coelectroporation of a plasmid-expressing human Shootin 1 cDNA resistant to the shRNA sequences (Fig. 4C). Statistical analysis using ANOVA with Tukey's multiplecomparison test revealed that the difference in the position of Shootin 1 shRNA versus that of control shRNA was statistically significant in 7 of 10 bins (Fig. $4 D$ ). In bins 1 and 5-8 the difference was extremely significant $(p<0.001)$, and in bins 4 and 9 the difference was very significant $(p<0.01)$. Rescue by coexpression of human Shootin 1 was most evident in six bins (bins 4-9). Shootin 1 knockdown also had consequences in postnatal brain (Fig. 4E-G). In mice treated with control shRNA, most cells reached cortical layers II-III; however, in Shootin1 shRNAtreated mice only a fraction of the cells was detected in these layers, while many cells were detected in the deeper layer IV. Cells were also detected in ectopic positions, in the intermediate zone, and in white matter. In control animals, Shootin 1 protein was detected in the leading edge of migrating neurons and in the developing axon (Fig. 4H,I). To test whether KIF20B affects neuronal migration and works in concert with Shootin 1 in migrating neurons, we monitored the position of migrating neurons for $4 \mathrm{~d}$ after in utero electroporation of control shRNA, Kif20b shRNA, Shootin 1 shRNAs, a combination of Kif20b shRNA plus Shootin 1 shRNAs, or Kif20b shRNA plus a human Kif20b expression plasmid (Fig. 4J-N). Kif20b knockdown in the developing brain impaired neuronal migration. The distribution of Kif20b shRNA-treated cells differed significantly from control (Fig. $4 R$ vs Q unpaired $t$ test: bin $1, p=0.0001$; bin $4, p=0.001$; bin $5, p=$ 0.004 ; bin $6, p=0.003$; bin $9, p=0.01$; bin $10, p=0.04$ ). As noted above, Shootin 1 shRNA treatment appeared to significantly impair neuronal migration, more so than treatment with Kif20b shRNA (Fig. 4 L,S). However, in animals treated with Shootin1 shRNAs, $4 \mathrm{~d}$ postelectroporation the distribution of pyramidal cells along the cortex did not vary from the distribution seen in cells treated with Kif20b shRNA, indicating that both treatments inhibit migration. Furthermore, combining Kif20b and Shootin 1 shRNAs did not enhance the effect seen with individual shRNA treatments (Fig. 4M). Coexpression of HA-tagged human 

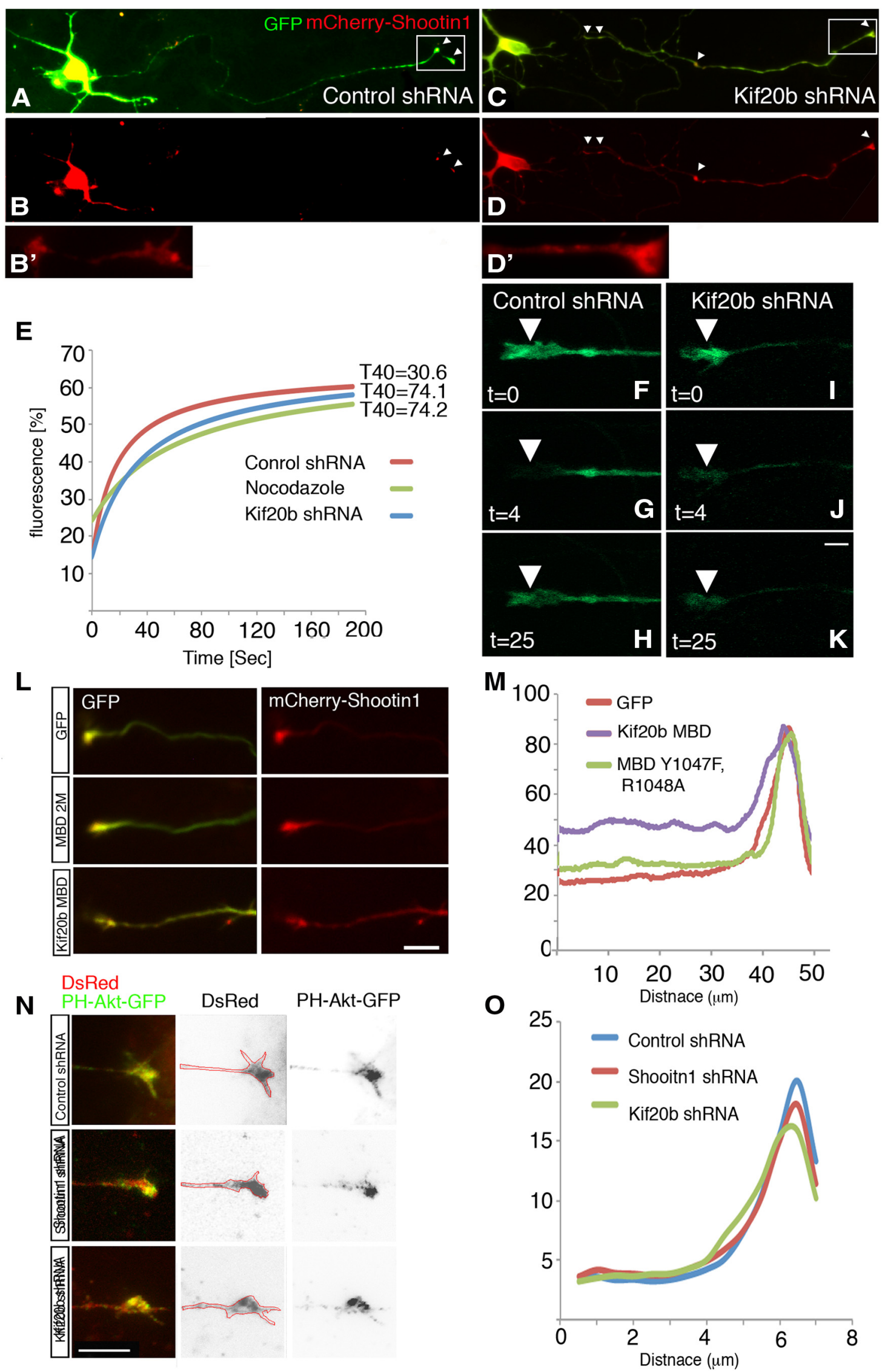

Figure 3. Shootin 1 transport to the growth cone is Kif20b dependent. Shootin 1 transport to the growth cone is Kif20b dependent. $\mathbf{A}-\boldsymbol{D}^{\prime}$, Hippocampal neurons in culture transfected with GFP, $m$ Cherry-Shootin1, and control $\left(\boldsymbol{A}-\boldsymbol{B}^{\prime}\right)$ or Kif20b shRNA $\left(\boldsymbol{C}-\boldsymbol{D}^{\prime}\right)$. Puncta of mCherry-Shootin1 in the growth cone and along the axon are indicated with white triangles. Insert, axonal growth cone of control-treated neurons $\left(\boldsymbol{B}^{\prime}\right)$ and Shootin1 shRNA-treated neurons $\left(\boldsymbol{D}^{\prime}\right)$. $\boldsymbol{E}-\boldsymbol{K}$, FRAP of Shootin1-GFP at the growth cone. Presented are fitted curves of the average (Figure legend continues.) 

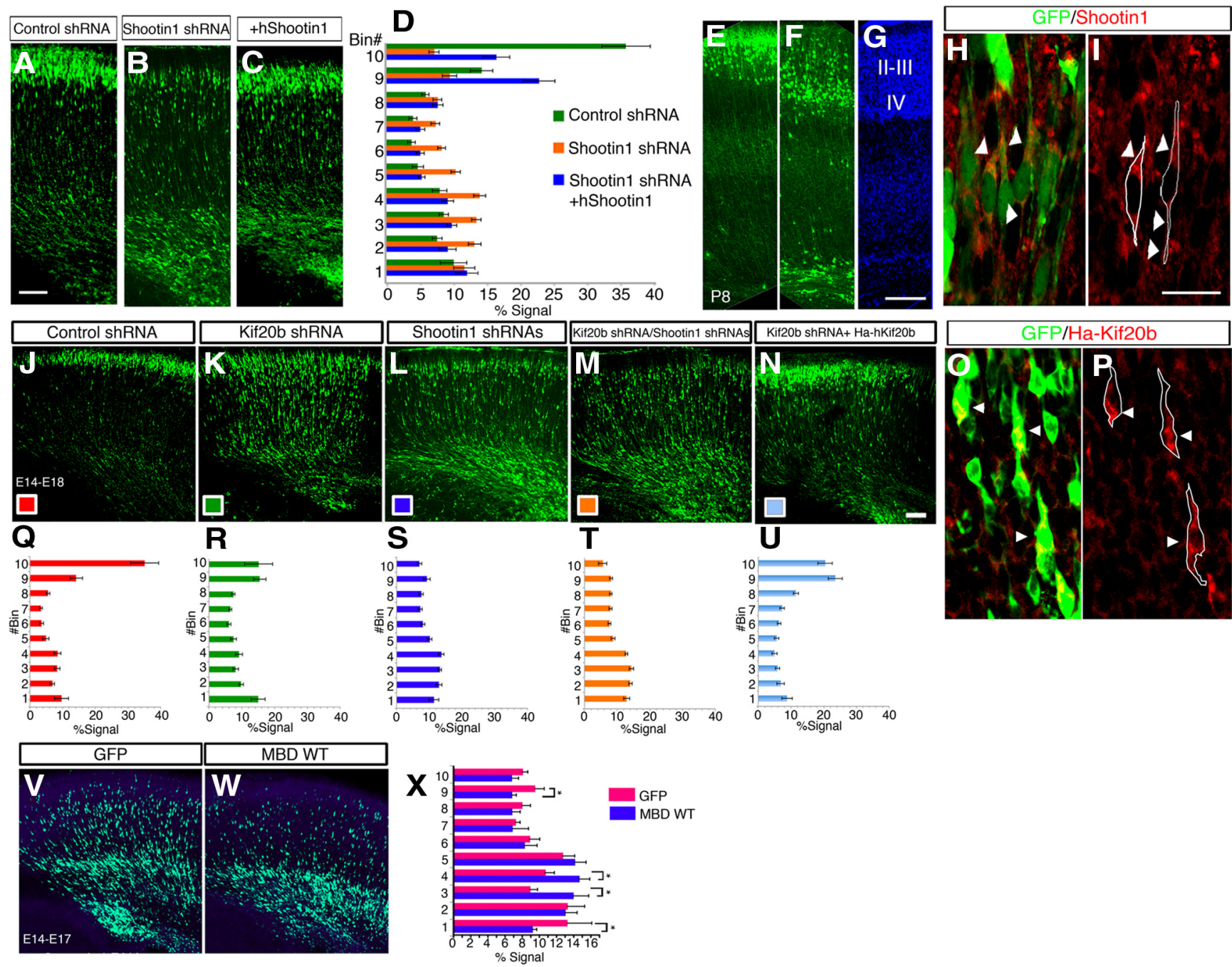

MBD WT

Figure 4. Shootin 1 knockdown inhibits neuronal migration. $\boldsymbol{A}-\boldsymbol{C}$, Brain sections from E18.5 mouse embryos, coelectroporated at E14.5 with control shRNA and GFP (A) or with a mixture of Shootin1 shRNA (B). Partial rescue of the migration phenotype following the introduction of shRNA-resistant hShootin1 (C). D, Average signal detected in arbitrary bins along the width of the cortex (bin 1, ventral; bin 10, dorsal). $\boldsymbol{E}-\boldsymbol{G}$, Brain section from P8 pup treated at E14.5 with control shRNA (E) or a mixture of Shootin1 shRNA (F). $\boldsymbol{G}$, Cux 1 staining (blue) in layers II-IV. $\boldsymbol{H}, \boldsymbol{I}$, Sections from E16.5 mouse brain sections, $2 \mathrm{~d}$ after in utero electroporation showing Shootin1 expression (red) in the leading edge and axon of bipolar neurons. J-N, E18.5 brain sections of E14.4 in utero electroporated mouse brains. Embryos were coelectroporated with GFP and indicated shRNA, Control shRNA (J), Kif20b shRNA (K), Shootin1 shRNAs (L), and a combination of Shootin1 shRNAs and Kif20b shRNA $(\boldsymbol{M}) . \boldsymbol{N}-\boldsymbol{P}$, Partial rescue of the migration phenotype after Kif20b knockdown is achieved after coexpression of shRNA-resistant human Ha-Kif20b. $\mathbf{0}, \boldsymbol{P}$, Expression of shRNA-resistant HA-hKif2Ob in the base of the leading edge of Kif20b shRNA-treated cells $(\boldsymbol{O}$ and $\boldsymbol{P}$; Ha red). $\mathbf{Q}-\boldsymbol{U}$, Relative signal in 10 arbitrary bins along the width of cortex measured from 10 sections of $3-4$ brains of each treatment (bin 10, the outer part of the cortical plate). $\boldsymbol{V}$ - $\boldsymbol{X}$, Kif20b-Shootin 1 interaction is required for radial migration in the developing cortex. Dominant-negative effect of the GFP-Kif20b MBD in E17.5 brain sections of E14.5 in utero electroporated mouse embryo brains ( $\boldsymbol{W}$ ) versus GFP alone $(\boldsymbol{V})$. The relative signal in 10 arbitrary bins along the width of cortex measured from 10 sections of 3-4 brains of each treatment ( $\left.{ }^{*} p<0.05\right)$. Scale bars: $A, 100 \mu \mathrm{m} ; \mathbf{G}, 200 \mu \mathrm{m} ; \mathbf{I}, 20 \mu \mathrm{m} ; \boldsymbol{N}, 100 \mu \mathrm{m}$.

KIF20B resistant to shRNA rescued impaired migration seen following Kif20b shRNA treatment (Fig. 4N,U). Human KIF20B expression was verified using immunostaining with anti-HA antibodies (Fig. 4O,P). Overall, these results suggest that KIF20B and Shootinl act in the same genetic pathway. We further probed the functional interaction between KIF20B and Shootin1 by expressing the Kif20b MBD fragment, which interfered in vitro with

(Figure legend continued.) recovery profile of 11 cells, and the average recovery time to $40 \%$ of the original signal (T40 in seconds). $\boldsymbol{F}-\boldsymbol{K}$, Time-lapse images of FRAP analysis (t, time in seconds). White triangles indicate bleached regions. $L, M$, Kif20b MBD but not double mutated Kif20b MBD affects the distribution of mCherry-Shootin 1 along the axon. N, PH-Akt-GFP (PIP3 reporter) localization at growth cones of transfected primary culture of hippocampal neurons treated with control, Shootin1, or Kif20b shRNA. $\mathbf{0}$, The average distribution of PH-Akt-GFP along the growth cone of $29-35$ cells. Scale bars: $K, 2 \mu \mathrm{m} ; \boldsymbol{L}, 3 \mu \mathrm{m} ; \boldsymbol{N}, 5 \mu \mathrm{m}$.
Shootin1/KIF20B binding (Fig. $4 \mathrm{~W}$ ), and analyzing the position of GFP-positive cells at stages E14-E17, $3 \mathrm{~d}$ after in utero electroporation (Fig. $4 V$ vs $W$ ). The position of Kif20b GFP-MBDexpressing cells differed from control cells in a statistically significant manner in four bins (Fig. $4 X$, bins 1,2,7, and 8). Collectively, our data indicate that KIF20B/Shootin1 interaction is important for proper neuronal migration in the developing cerebral cortex.

Shootin1 and Kif20b knockdown alters neuronal polarization Previous studies have demonstrated the role of Shootin1 in polarization of primary hippocampal neurons (Toriyama et al., 2006; Shimada et al., 2008). Therefore, we tested the possible role of Shootin1/Kif20b interaction for polarization of primary hippocampal neurons. Toward that end we transfected primary hippocampal neurons with either control shRNA or control GFP, 


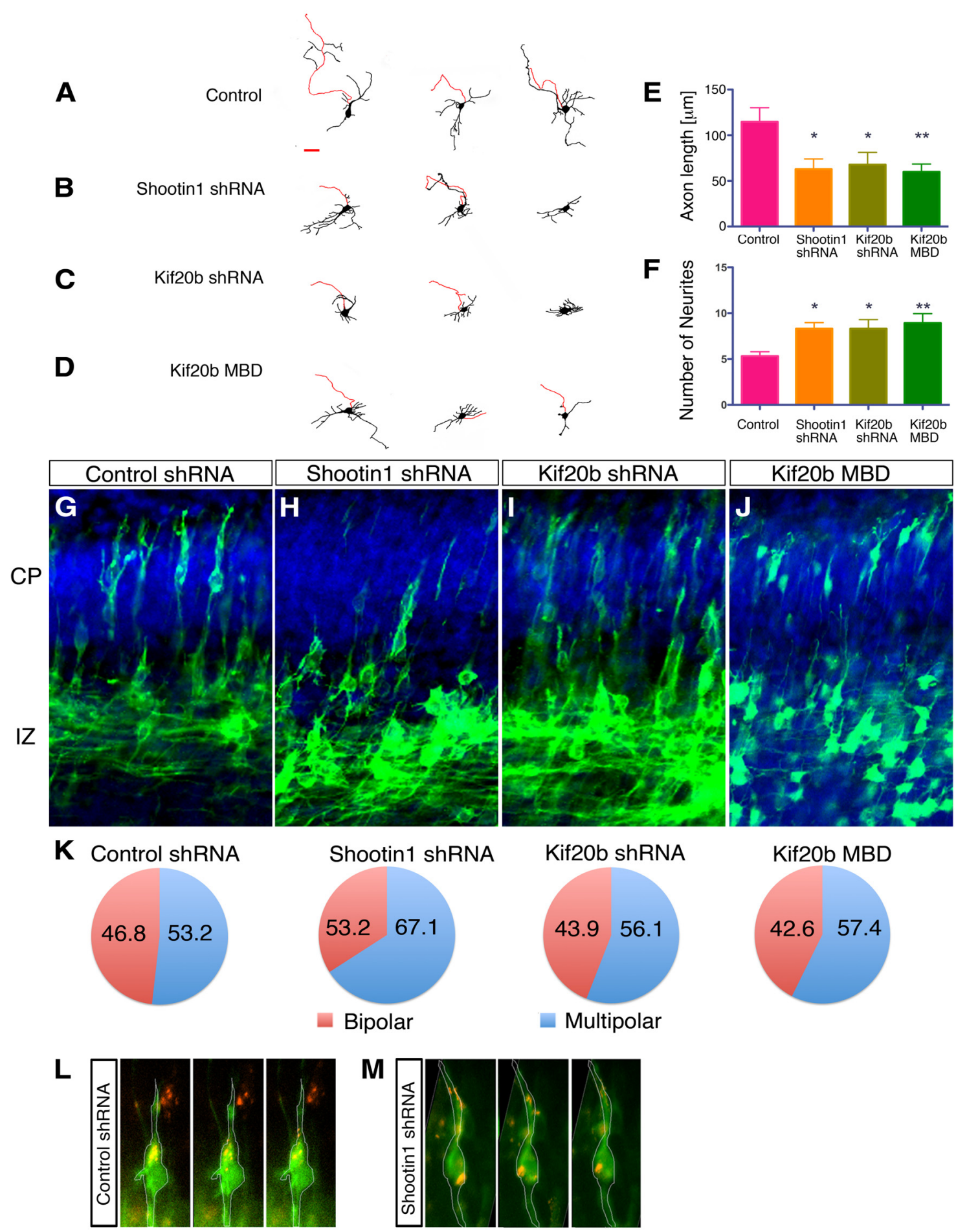

Figure 5. Shootin 1 and Kif20b are required for neuronal polarization. $\boldsymbol{A}-\boldsymbol{F}$, Primary hippocampal neurons prepared from E18 mice embryos were coelectroporated with GFP and either control shRNA, a mixture of Shootin 1 shRNA, Kif20b shRNA, or the MBD of Kif20b (Kif20b-MBD fused to GFP). After $4 \mathrm{~d}$ in cultures the cells were stained with MAP2 and their morphology was traced. Outline of representative cells are presented, axons are shown in red. $\boldsymbol{E}, \boldsymbol{F}$, Measurements of the axon length and the number of neurite per cells are presented; ${ }^{*} p<0.05$, ${ }^{* *} p<0.01$. G-J, Inhibition of multipolar to bipolar transition. E12.5 brains were electroporated with Cre-activated Lyn-GFP, $(r e$, and control shRNA ( $G$ ), a mixture of Shootin1 shRNA (H), or Kif20b shRNA ( $\boldsymbol{I})$ or Kif20b MBD fused to GFP (J). All embryos were harvested $2 \mathrm{~d}$ postelectroporation. Slices were stained with anti-GFP antibodies and the proportion of multipolar and bipolar cells in slices was quantified. $\boldsymbol{K}$, Pie graphs representing results form 9-13 sections taken from four individual brains. $L$, $\boldsymbol{M}$, Time-lapse images from movies showing a pyramidal cell in organotypic slices prepared from E16.5 brains electroporated at E14.5 with control shRNA $(\boldsymbol{L})$ or Shootin1 ShRNA $(\boldsymbol{M})$. mCherry-Golgi marker in red and membranal GFP in green.

Shootin1 shRNA, Kif20b shRNA, or Kif20b MBD before their plating on coated slides (Fig. $5 A-D$, respectively). The cells were allowed to repolarize and were cultured for $4 \mathrm{~d}$. Tracing the outline of the neurons, where the axon (MAP2 negative) is indicated in red, demonstrated a qualitative difference in the structure of the treated neurons. We assessed neuronal polarization by two criteria: measurement of the axon length and counting the number of neurites (Fig. $5 E, F$ ). Reduction in the levels of either Shootin1 or Kif20b or interference with Shootin1/Kif20b interaction by expression of the dominant-negative fragment of Kif20b MBD 
all resulted in impairment of neuronal polarization. Our studies of neuronal migration prompted us to ask whether neuronal polarization in vivo is altered by interference with Shootin 1/Kif20b interactions. To do so, we analyzed the multipolar fraction of neurons in utero electroporated at E12.5 and analyzed at E14.5 (Fig. $5 G-K$ ). The different time points for electroporation and for analysis were chosen to increase the relative proportion of cells with multipolar morphology. Analysis of 9-13 brain slices demonstrated that both in control and treated cells approximately half the cells are found with multipolar morphology (Fig. $5 K)$. Shootin 1 shRNA significantly increased the proportion of multipolar cells in comparison with control shRNA treatment (mean \pm SEM, $67.08 \pm 3.9 \%$ vs $53.24 \pm 2.5 \%$, ANOVA, $p=$ 0.022 considered highly significant). Treatments with Kif20b shRNA or Kif20b MBD did not statistically differ from control treatments.

Given the multipolar morphology of most Shootin1 shRNAtreated cells, we asked whether the subset of shRNA-treated neurons that do adopt a bipolar morphology was polarized as well as control neurons. Toward that end, we monitored the position of the Golgi apparatus as a marker of polarity. Studies of primary hippocampal neurons indicate that the Golgi orients toward the forming axon following the accumulation of $\mathrm{N}$-cadherin there (Gärtner et al., 2012). Our time-lapse microscopy showed that the Golgi is motile in polarizing neurons in vivo. However, whereas in control cells the Golgi was always found in the leading edge, in the subset of Shootin 1 shRNA-treated cells exhibiting bipolar morphology, the Golgi was not polarized and extended into regions including but not limited to the leading edge (Fig. $5 L, M)$. Collectively, our results suggest that Shootin1 regulates neuronal polarization in migrating neurons.

\section{KIF20B and Shootin1 impair the multipolar to bipolar transition}

To enable monitoring of individual cells and dynamic morphology changes using time-lapse microscopy, we titrated the expression of membranal-GFP by the activity of Cre-loxP-mediated recombination (Morin et al., 2007). As described above, electroporation was performed at E12.5 and the brains were sliced $2 \mathrm{~d}$ later, at E14.5. Early born postmitotic neurons were labeled with the T $\alpha$-1 tubulin promoter (Gloster et al., 1994) driving Cre expression. Our experimental setting resulted in labeling of sparse cells, as they emerge from the ventricular zone; at the beginning of the experiment many cells were multipolar and polarization occurred during the $20 \mathrm{~h}$ course of the experiment (Figure $5 \mathrm{~L}$, $M)$. Representative images of treated cells at the beginning and end of the $20 \mathrm{~h}$ of time-lapse imaging are shown (Fig. 6A-C). Several features were noted following analysis of single cells. At the initial time point, $2 \mathrm{~d}$ after electroporation (E12.5-E14.5), most Shootin 1 shRNA-treated and Kif20b shRNA-treated cells showed multipolar morphology. These cells exhibited more neurites per cell (mean number of neurites \pm SEM, $4.54 \pm 0.45$, $7.72 \pm 0.66,5.72 \pm 0.3$ for control shRNA, Shootin 1 shRNA, and Kif20b shRNA, respectively, $t$ test of Shootin 1 and control $p=$ 0.0007 , Kif20b and control $p=0.0374$ ) (Fig. 6D). At an intermediate time point, after $10 \mathrm{~h}$, control cells showed initiation of polarization: the proportion of cells with multiple neurites decreased and the length of the neurites was significantly longer compared with those seen in either Shootin1 shRNA-treated $(p<0.01)$ or Kif20b shRNA-treated $(p<0.05)$ cells (Fig. $6 E$ ) $(40.60 \pm 8.53,21.62 \pm 1.63,23.9 \pm 3.88 \mu \mathrm{m})$. The mean number of neurites in control-treated cells $(3.81 \pm 0.44)$ differed significantly from Shootin 1 shRNA-treated cells $(6.09 \pm 0.88, p=0.03)$ and from Kif20b shRNA-treated cells $(5.63 \pm 0.45, p=0.009)$. At the final $(20 \mathrm{~h})$ time point, most control cells had completed their polarization: cells appeared to be bipolar with long dendrites and a visible axon (mean number of neurites, $2.81 \pm 0.22$ ). In contrast, many Shootin1 shRNA-treated cells remained multipolar with short neurites (mean number of neurites, $6.81 \pm 0.71, p=$ 0.0002 ). Kif20b knockdown cells exhibited fewer neurites than at the intermediate time point, an observation suggesting that they have the capacity to polarize $(4 \pm 0.26, p=0.003)$. Nevertheless these neurites were relatively short $(p<0.001,62.20 \pm 4.01$, $25.1 \pm 1.732,36.56 \pm 4.09$ for control shRNA, Shootin 1 shRNA, and Kif20b shRNA, respectively). At all time points tested, the number of neurites per cell observed following knockdown of either Shootin1 shRNA or Kif20b shRNA was higher than that observed following control treatment $(p=0.024,0.0156$, paired $t$ test, Shootin 1 shRNA or Kif20b shRNA vs control, respectively). The polarization of cells in organotypic slices was also monitored by examining the relative angle adopted by the longest processes over time (Fig. $6 G-I$ ). At the initial time point, neurites were oriented randomly with no specific angle preference. At the final time point, $>80 \%$ of control neurites (mostly bipolar cells) were oriented in a manner enabling proper migration such that the leading edge was pointed to the pial surface and the trailing edge toward the ventricle. In cells treated with Shootin 1 or Kif20b shRNA, $\sim 68 \%$ of neurites were oriented toward the pial surface. Collectively, our data indicate that knockdown of Shootin1 or Kif20b impairs neuronal polarization, with Shootin 1 knockdown being more potent than that of Kif20b knockdown.

\section{Discussion}

The molecular mechanisms underlying early polarization of pyramidal neurons in the developing telencephalon are not completely understood. We chose to examine the roles of Shootin 1 in this process since we speculated that in primary cortical neurons in the brain it may act in a way similar to that described for polarization of primary hippocampal neurons (Toriyama et al., 2006, 2010, 2013; Shimada et al., 2008). Shootin1 is highly expressed in the developing brain and its expression pattern resembles that of other genes known to govern neuronal migration such as Dcx (Francis et al., 1999). Shootin1 knockdown inhibited neuronal migration, and neurons retained a multipolar morphology for an extended period of time. Furthermore, defects in polarization were evident by the position and lack of clustering of the Golgi apparatus.

\section{Shootin 1 and the cytoskeleton}

Unexpectedly, we detected Shootin1 in the MAP fraction and it colocalized with microtubules in neuronal growth cones and in interphase and mitotic HeLa cells. We found the interaction between Shootin 1 and microtubules to be indirect, and mediated by MAP(s) (Fig. 7A). Previous studies demonstrated a tight link between Shootinl and the actin cytoskeleton (Toriyama et al., 2006; Shimada et al., 2008), as well as an interaction with an actin binding protein, profilin (Veniere et al., 2009). Furthermore, recent studies indicated that Pak-1 phosphorylated Shootin 1 is in a tighter association with actin (Toriyama et al., 2013). The transport of Shootin 1 along the axon was impaired following the addition of blebbistatin (Toriyama et al., 2006). Furthermore, Shootin 1 interacted with actin filament retrograde flow, which was inhibited by addition of cytochalasin D (Shimada et al., 2008). Our findings indicate that intact microtubules are also required for proper mobilization of Shootin 1 in the growth cone. These results do not contradict the interaction of Shootin 1 with 

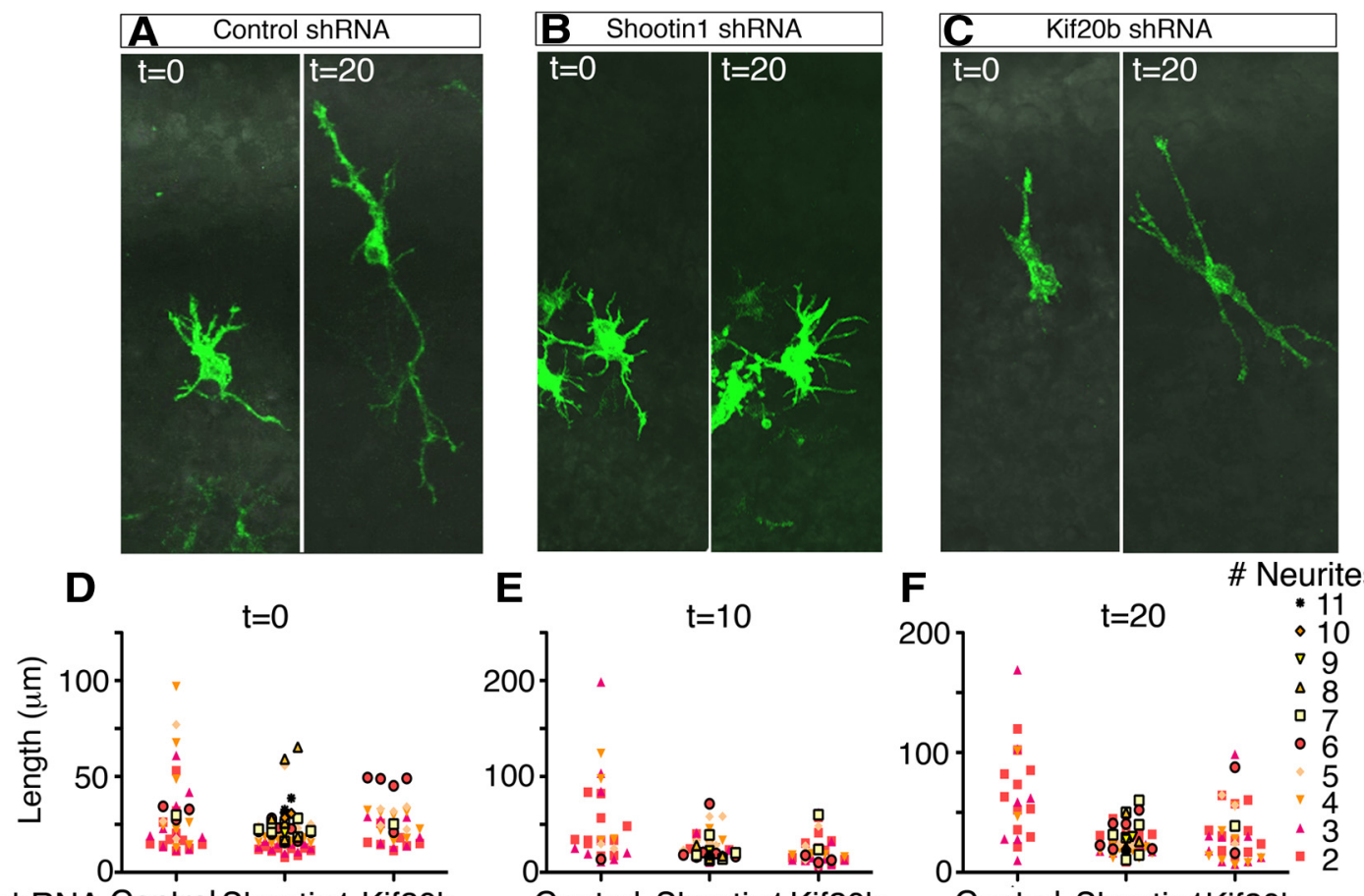

shRNA Control Shootin1 Kif20b

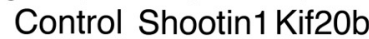

Control Shootin1Kif2Ob

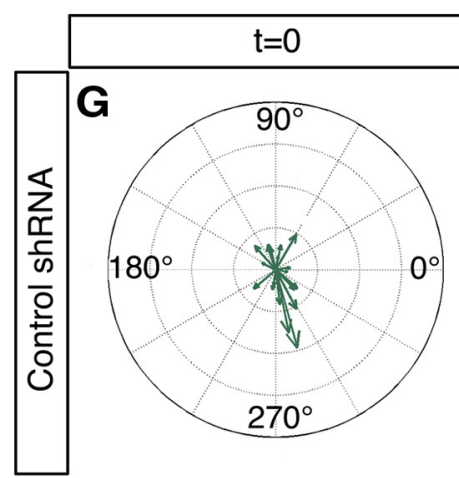

\begin{tabular}{|l|l|}
$\mathrm{t}=10$ & $\mathrm{t}=20$ \\
\hline
\end{tabular}
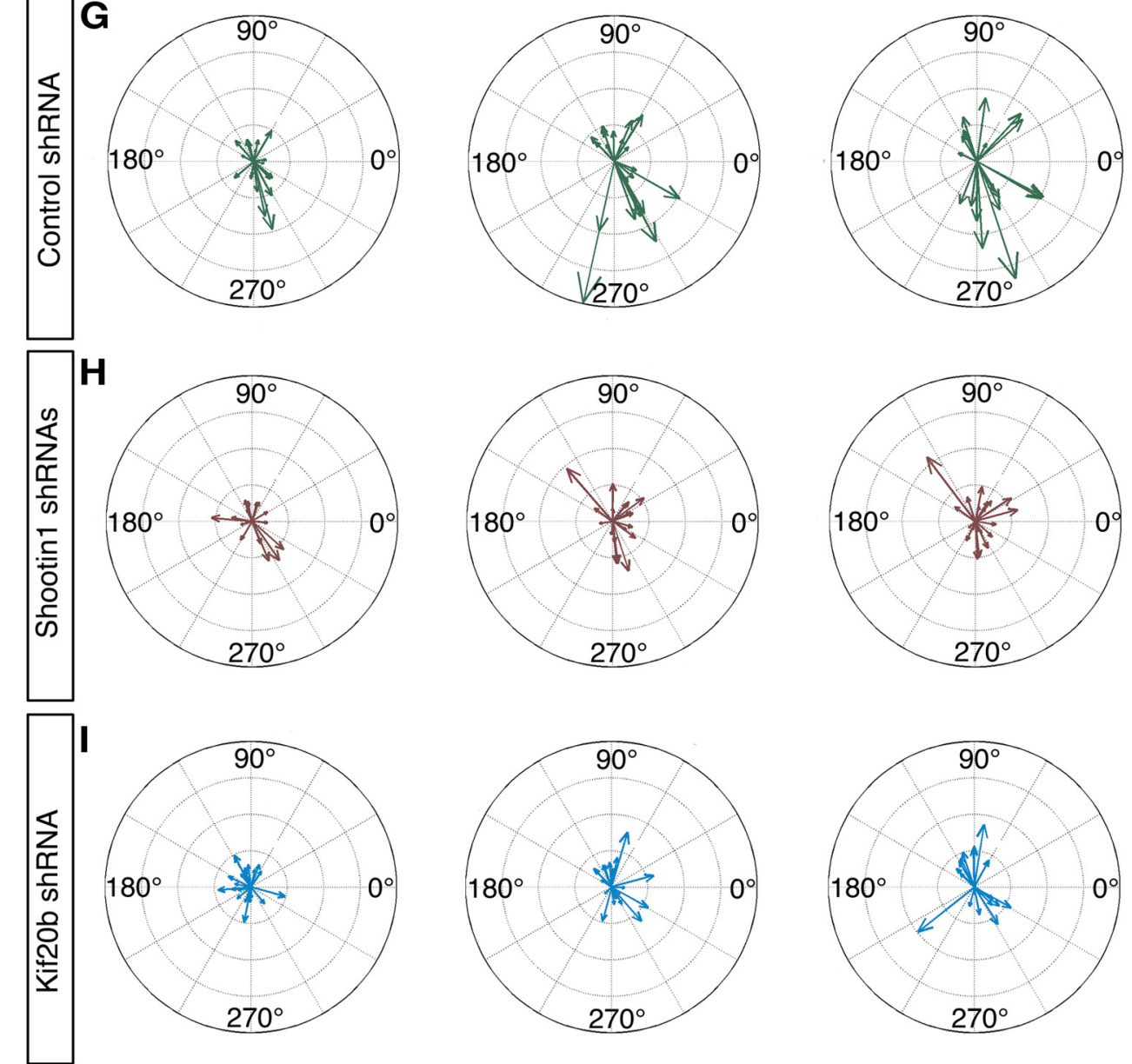

Figure 6. In vivo polarization of pyramidal neurons depends on Shootin1 and Kif20b. $\boldsymbol{A}$-C, Time-lapse images from labeling of neurons in organotypic slices (E14.5). Cells were labeled with Cre-activated membranal GFP (Lyn-GFP) and indicated shRNA at E12.5; representative images were taken at the beginning of the experiment $(t=0)$ and after $20 \mathrm{~h}$ in culture $(t=20)$. $\boldsymbol{D}-\boldsymbol{F}$, Measurements of 11 single cells in E14.5 organotypic slices show the distribution of the number of neurites and their length at three time points; 0,10 , and $20 \mathrm{~h}$ in culture. (Figure legend continues.) 


\section{A}

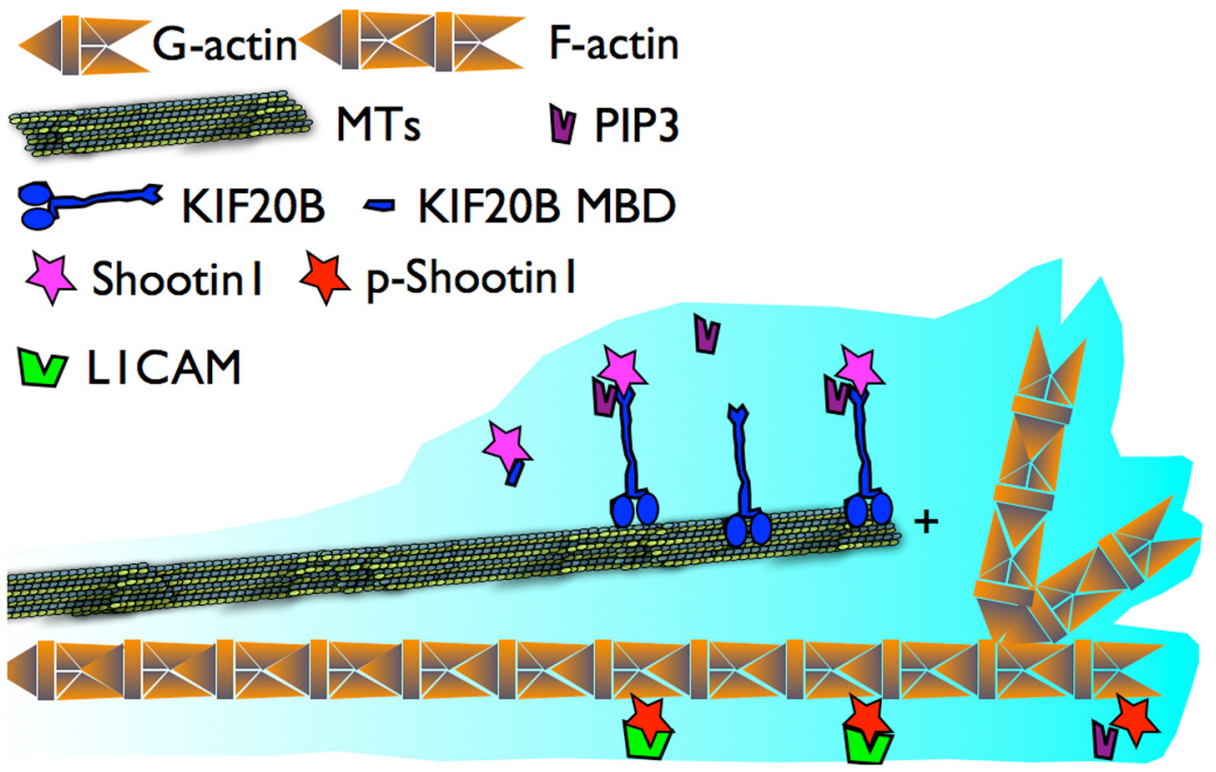

B

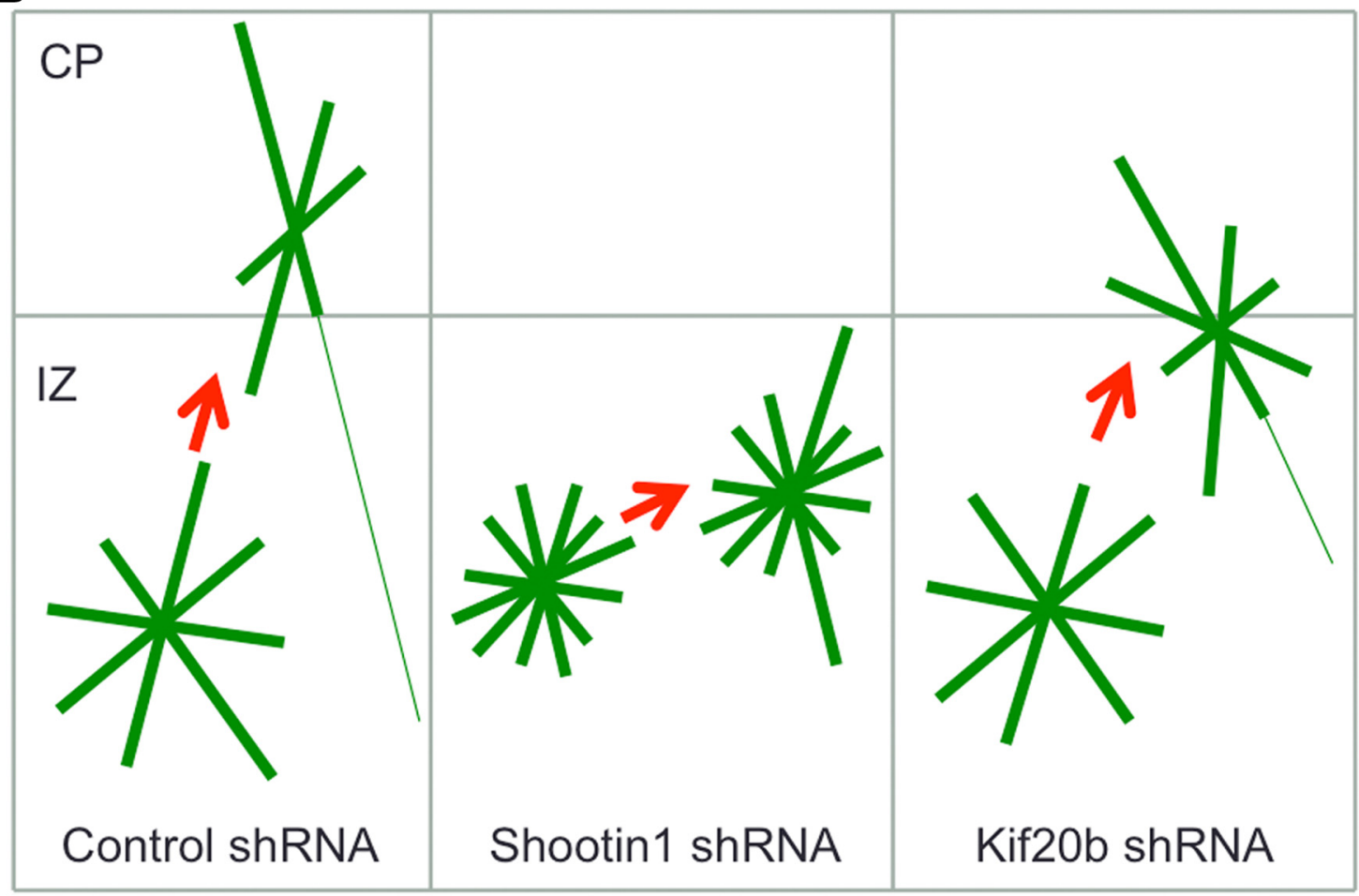

Figure 7. Schematic presentation of the role of Kif20b and Shootin 1 in neuronal polarization. $\boldsymbol{A}$, The molecular motor KIF20B (blue) mobilizes Shootin 1 (pink or red stars) and PIP3 vesicles (purple structures) to the growth cone toward the plus ends of microtubules. Shootin 1 is mobilized along the microtubules (green) and it is deposited at the basis of the growth cone. The front edge of the growth cone is actin rich (orange fibers). Shootin1 also complexes with PI 3-kinase, which produces local PIP3 in the growth cone. At the growth cone Cdc42 and Rac1 induce Pak1-mediated Shootin1 phosphorylation (red stars). PAK1 phosphorylated Shootin1 enhances the "clutch" engagement through interaction with L1CAM (green) and F-actin. B, Polarization of pyramidal neurons in the developing cortex relies on Shootin1 and KIF20B. Multipolar cells at the intermediate zone (IZ) are retracting processes and elongating a future axon (thin green line) and a predominant basal process. The polarized cells invade the cortical plate (CP). Shootin 1 knockdown causes cells to appear highly branched and to spend longer periods of time in the $\mathrm{IZ}$ at the multipolar stage. Kif20b knockdown partially recapitulates this phenotype.

actin; in fact, several microtubule-associated proteins reportedly function with the actin cytoskeleton. In an analogous way, we

(Figure legend continued.) $\quad \mathbf{G}-\mathbf{I}$, Directionality of the two longest neurites in 10 cells per treatment ( $\boldsymbol{G}$, control shRNA; $\boldsymbol{H}$, mixture of Shootin1 shRNA; $\boldsymbol{I}$, Kif20b shRNA) at three time points along the polarization process $(t=0 \mathrm{~h}, t=10 \mathrm{~h}, t=20 \mathrm{~h})$. The $90^{\circ}$ angle indicates the direction of the pial surface; the radius of the circles is $200 \mu \mathrm{m}$. found that the DCX phosphorylated by JNK2 is more enriched in the actin-rich part of the growth cone (Gdalyahu et al., 2004). Furthermore, it should be noted that the activities of major cytoskeleton elements require tight coordination, especially in mi- 
grating neurons. For example, DCX is a well known MAP (Francis et al., 1999; Gleeson et al., 1999; Horesh et al., 1999; Moores et al., 2004,2006), yet it also interacts with actin directly and indirectly and can alter actin polymerization in vitro and in vivo (Tsukada et al., 2005, 2006; Shmueli et al., 2006; Bielas et al., 2007; Tint et al., 2009). LIS1 is a nonconventional MAP, which can interact directly with tubulin (Sapir et al., 1997), but may also interact with microtubules indirectly via CLIP-170 (Coquelle et al., 2002) or via the dynein-dynactin molecular complex (Xiang et al., 1995; Liu et al., 1999, 2000; Swan et al., 1999; Efimov and Morris, 2000; Faulkner et al., 2000; Lei and Warrior, 2000; Niethammer et al., 2000; Sasaki et al., 2000; Smith et al., 2000; for review see Morris et al., 1998; Reiner, 2000). However, LIS1 was also found to affect the actin cytoskeleton via the activity of the small GTPase CDC42 (Kholmanskikh et al., 2003, 2006; Bi et al., 2009).

\section{KIF20B, a mitotic kinesin}

Our unbiased yeast two-hybrid screen detected a candidate MAP for mediating the Shootin $1 /$ microtubule interaction, KIF20B, a member of the kinesin superfamily of microtubuleassociated motor proteins (Miki et al., 2005; Hirokawa et al., 2009). The interaction between the two proteins required the $\mathrm{N}$-terminal part of Shootin 1 and a short tyrosine-containing peptide of KIF20B (termed MBD amino acids 1002-1059). This interaction does not overlap with the Shootin1/actin interaction domain, which mapped to a C-terminal part of Shootin 1 (Shimada et al., 2008). KIF20B is primarily known as a mitotic kinesin. It is heavily phosphorylated during mitosis and was first identified as one of the MPM2 antigens (Westendorf et al., 1994). Later studies demonstrated that KIF20B exhibited microtubule-dependent molecular motor activities and binding to microtubules, and was required for completion of cytokinesis (Abaza et al., 2003). During mitosis it interacts with PIN1 and PRC1 (Kamimoto et al., 2001; Kanehira et al., 2007). Nevertheless, so far its role in neuronal cells has not been studied, although it has been postulated that KIF20B may function in postmitotic neurons due to the presence of autoantibodies of this protein in patients with idiopathic ataxia (Fritzler et al., 2000; Zochodne et al., 2003). As a member of the kinesin superfamily, it may participate in polarization regulation through transport of specific cargoes. Some cargoes may be transported by one kinesin, while others may be transported by more than one molecular motor to deliver them to the correct subcellular localization. For example, synaptic vesicle precursors are transported by KIF5 and KIF1A or by KIF1B, but NMDA receptors are transported by KIF17 (for review, see Hirokawa et al., 2009). Our study indicates that KIF20B mobilizes Shootin1 (Fig. 7A). Furthermore, in agreement with previous findings (Toriyama et al., 2006), PIP3 accumulation to neuronal growth cones was impaired following Shootin 1 knockdown. Kif20b knockdown also produced a similar phenotype. Previously, it has been demonstrated that PIP3 accumulation in a cell's longest neurite induced its development into an axon (Shi et al., 2003; Ménager et al., 2004). One demonstrated mechanism underlying PIP3 accumulation at the tip of the axon is its motor-dependent transport by GAKIN, also known as KIF13B, via its interaction with the adaptor protein PIP3BP/centaurin- $\alpha$ (Horiguchi et al., 2006). An additional possibility may be through activation of upstream PI 3-kinase signaling (Aoki et al., 2005). It was previously demonstrated that Shootin 1 interacts with PI 3-kinase and is required for localized PI 3-kinase activity in growth cones of hippocampal neurons (Toriyama et al., 2006). Our studies demonstrated that PIP3 accumulation includes not only increased localized activity of the kinase but also transport, which is mediated by KIF20B (Fig. 7A).

Our findings demonstrated that both Shootin 1 and KIF20B regulate radial migration within the developing telencephalon (Fig. 7B). Among multiple mitotic kinesins, it has been suggested that KIF15 participates in regulation of neuronal migration based on its expression pattern and subcellular localization (Buster et al., 2003). In addition, KIF11 has been demonstrated to regulate migration of cortical neurons (Falnikar et al., 2011). Those authors and others (Haque et al., 2004; Yoon et al., 2005; Myers and Baas, 2007) have suggested that KIF11 acts as a brake on interactions between microtubules in developing neurons. KIF11 depletion or inhibition in cultured sympathetic neurons resulted in faster growing axons, which did not turn properly (Nadar et al., 2008). KIF11 knockdown in pyramidal neurons resulted in faster migration, and conversely its overexpression inhibited neuronal migration (Falnikar et al., 2011). Thus, the mechanism of action of KIF20B is very different from that of Kif11. We propose that following either Kif20b knockdown, which perturbs Shootin 1 transport, or Shootin1 knockdown, neuronal migration and polarization are impaired.

\section{Shootin 1/KIF20B polarity proteins}

Shootin 1 belongs to a growing list of proteins that regulate neuronal polarization and function in regulation of neuronal migration. MARK2/Par-1 regulates neuronal polarity in cultured neurons (Biernat et al., 2002; Chen et al., 2006; Terabayashi et al., 2007). In vivo, MARK2/Par-1 affects the multipolar to bipolar transition (Sapir et al., 2008a), radial neuronal migration to the cerebral cortex (Sapir et al., 2008a), and the rostral migratory stream to the olfactory bulb (MejiaGervacio et al., 2012). In radially migrating neurons, one function of MARK2/Par-1 is to phosphorylate DCX (Sapir et al., 2008b). Our results show the importance of the Shootin 1/ Kif20 polarity complex in migrating neurons. Whereas the role of Shootin 1 in regulation of polarization of primary hippocampal has been documented (Toriyama et al., 2006; Shimada et al., 2008), we show here that Kif20b and Shootin1/ Kif20b are also important in polarization of primary hippocampal neurons as well as in regulation of polarization and migration of pyramidal neurons (Fig. $7 B$ ). Furthermore, our studies ascribe new polarity functions for KIF20B, which in primary hippocampal neurons mediates the transport of Shootin 1 and PIP3, and in migrating neurons is involved in regulation of polarization and migration (Fig. $7 B$ ). Our data suggest that Shootin 1/KIF20B not only form a complex, but also act in the same genetic pathway. Knockdown of either one impairs neuronal migration, where the effect of Shootin 1 knockdown was more robust than that of KIF20B, and the combined effect of both treatments did not result in a synergistic effect. The impact of Shootin1-KIF20B interaction was also demonstrated by expression of the MBD of KIF20B, which also impaired neuronal migration.

Our in vivo analysis clearly supports a role for Shootin 1 and KIF20B in the important multipolar to bipolar transition. We assessed several polarization features: control cells exhibited progressive decline in the number of neurites, and remaining neurites lengthened and oriented along the migration axis. Shootin1shRNA-treated or Kif20b shRNA-treated cells exhibited more and shorter neurites, which were less oriented. Shootin 1 
knockdown cells were more strongly impaired, suggesting Shootin1 may function to regulate additional, unidentified molecule(s) governing the polarization process.

\section{References}

Abaza A, Soleilhac JM, Westendorf J, Piel M, Crevel I, Roux A, Pirollet F (2003) M phase phosphoprotein 1 is a human plus-end-directed kinesinrelated protein required for cytokinesis. J Biol Chem 278:27844-27852. CrossRef Medline

Angevine JB Jr, Sidman RL (1961) Autoradiographic study of cell migration during histogenesis of cerebral cortex in the mouse. Nature 192: 766-768. CrossRef Medline

Aoki K, Nakamura T, Fujikawa K, Matsuda M (2005) Local phosphatidylinositol 3,4,5-trisphosphate accumulation recruits Vav2 and Vav3 to activate $\mathrm{Rac1} / \mathrm{Cdc} 42$ and initiate neurite outgrowth in nerve growth factor-stimulated PC12 cells. Mol Biol Cell 16:2207-2217. CrossRef Medline

Arimura N, Kaibuchi K (2007) Neuronal polarity: from extracellular signals to intracellular mechanisms. Nat Rev Neurosci 8:194-205. CrossRef Medline

Ayala R, Shu T, Tsai LH (2007) Trekking across the brain: the journey of neuronal migration. Cell 128:29-43. CrossRef Medline

Bartel P, Chien CT, Sternglanz R, Fields S (1993) Using the two-hybrid system to detect protein-protein interactions. In: Cellular interactions in development: a practical approach (Hartley DA, ed), pp 153-179. Oxford, UK: Oxford UP.

Bi W, Sapir T, Shchelochkov OA, Zhang F, Withers MA, Hunter JV, Levy T, Shinder V, Peiffer DA, Gunderson KL, Nezarati MM, Shotts VA, Amato SS, Savage SK, Harris DJ, Day-Salvatore DL, Horner M, Lu XY, Sahoo T, Yanagawa Y, et al. (2009) Increased LIS1 expression affects human and mouse brain development. Nat Genet 41:168-177. CrossRef Medline

Bielas SL, Serneo FF, Chechlacz M, Deerinck TJ, Perkins GA, Allen PB, Ellisman MH, Gleeson JG (2007) Spinophilin facilitates dephosphorylation of doublecortin by PP1 to mediate microtubule bundling at the axonal wrist. Cell 129:579-591. CrossRef Medline

Biernat J, Wu YZ, Timm T, Zheng-Fischhöfer Q, Mandelkow E, Meijer L, Mandelkow EM (2002) Protein kinase MARK/PAR-1 is required for neurite outgrowth and establishment of neuronal polarity. Mol Biol Cell 13:4013-4028. CrossRef Medline

Buster DW, Baird DH, Yu W, Solowska JM, Chauvière M, Mazurek A, Kress M, Baas PW (2003) Expression of the mitotic kinesin Kif15 in postmitotic neurons: implications for neuronal migration and development. J Neurocytol 32:79-96. CrossRef Medline

Chen YM, Wang QJ, Hu HS, Yu PC, Zhu J, Drewes G, Piwnica-Worms H, Luo ZG (2006) Microtubule affinity-regulating kinase 2 functions downstream of the PAR-3/PAR-6/atypical PKC complex in regulating hippocampal neuronal polarity. Proc Natl Acad Sci U S A 103:85348539. CrossRef Medline

Coquelle FM, Caspi M, Cordelières FP, Dompierre JP, Dujardin DL, Koifman C, Martin P, Hoogenraad CC, Akhmanova A, Galjart N, De Mey JR, Reiner O (2002) LIS1, CLIP-170's key to the dynein/dynactin pathway. Mol Cell Biol 22:3089-3102. CrossRef Medline

Efimov VP, Morris NR (2000) The LIS1-related NUDF protein of Aspergillus nidulans interacts with the coiled-coil domain of the NUDE/RO11 protein. J Cell Biol 150:681-688. CrossRef Medline

Fägerstam LG, Frostell-Karlsson A, Karlsson R, Persson B, Rönnberg I (1992) Biospecific interaction analysis using surface plasmon resonance detection applied to kinetic, binding site and concentration analysis. J Chromatogr 597:397-410. CrossRef Medline

Falnikar A, Tole S, Baas PW (2011) Kinesin-5, a mitotic microtubuleassociated motor protein, modulates neuronal migration. Mol Biol Cell 22:1561-1574. CrossRef Medline

Faulkner NE, Dujardin DL, Tai CY, Vaughan KT, O'Connell CB, Wang Y, Vallee RB (2000) A role for the lissencephaly gene LIS1 in mitosis and cytoplasmic dynein function. Nat Cell Biol 2:784-791. CrossRef Medline

Formstecher E, Aresta S, Collura V, Hamburger A, Meil A, Trehin A, Reverdy C, Betin V, Maire S, Brun C, Jacq B, Arpin M, Bellaiche Y, Bellusci S, Benaroch P, Bornens M, Chanet R, Chavrier P, Delattre O, Doye V, et al. (2005) Protein interaction mapping: a Drosophila case study. Genome Res 15:376-384. CrossRef Medline

Francis F, Koulakoff A, Boucher D, Chafey P, Schaar B, Vinet MC, Friocourt G, McDonnell N, Reiner O, Kahn A, McConnell SK, Berwald-Netter Y,
Denoulet P, Chelly J (1999) Doublecortin is a developmentally regulated, microtubule-associated protein expressed in migrating and differentiating neurons. Neuron 23:247-256. CrossRef Medline

Fritzler MJ, Kerfoot SM, Feasby TE, Zochodne DW, Westendorf JM, Dalmau JO, Chan EK (2000) Autoantibodies from patients with idiopathic ataxia bind to M-phase phosphoprotein-1 (MPP1). J Investig Med 48:28 39. Medline

Fromont-Racine M, Rain JC, Legrain P (1997) Toward a functional analysis of the yeast genome through exhaustive two-hybrid screens. Nat Genet 16:277-282. CrossRef Medline

Fygenson DK, Braun E, Libchaber A (1994) Phase diagram of microtubules. Phys Rev E Stat Phys Plasmas Fluids Relat Interdiscip Topics 50:1579-1588. CrossRef Medline

Gärtner A, Fornasiero EF, Munck S, Vennekens K, Seuntjens E, Huttner WB, Valtorta F, Dotti CG (2012) N-cadherin specifies first asymmetry in developing neurons. EMBO J 31:1893-1903. CrossRef Medline

Gdalyahu A, Ghosh I, Levy T, Sapir T, Sapoznik S, Fishler Y, Azoulai D, Reiner O (2004) DCX, a new mediator of the JNK pathway. EMBO J 23:823832. CrossRef Medline

Gleeson JG, Lin PT, Flanagan LA, Walsh CA (1999) Doublecortin is a microtubule-associated protein and is expressed widely by migrating neurons. Neuron 23:257-271. CrossRef Medline

Gloster A, Wu W, Speelman A, Weiss S, Causing C, Pozniak C, Reynolds B, Chang E, Toma JG, Miller FD (1994) The T alpha 1 alpha-tubulin promoter specifies gene expression as a function of neuronal growth and regeneration in transgenic mice. J Neurosci 14:7319-7330. Medline

Gloster A, El-Bizri H, Bamji SX, Rogers D, Miller FD (1999) Early induction of Talphal alpha-tubulin transcription in neurons of the developing nervous system. J Comp Neurol 405:45-60. CrossRef Medline

Goldin M, Segal M, Avignone E (2001) Functional plasticity triggers formation and pruning of dendritic spines in cultured hippocampal networks. J Neurosci 21:186-193. Medline

Haque SA, Hasaka TP, Brooks AD, Lobanov PV, Baas PW (2004) Monastrol, a prototype anti-cancer drug that inhibits a mitotic kinesin, induces rapid bursts of axonal outgrowth from cultured postmitotic neurons. Cell Motil Cytoskeleton 58:10-16. CrossRef Medline

Hatten ME (1999) Central nervous system neuronal migration. Annu Rev Neurosci 22:511-539. CrossRef Medline

Hatten ME (2002) New directions in neuronal migration. Science 297: 1660-1663. CrossRef Medline

Hirokawa N, Noda Y, Tanaka Y, Niwa S (2009) Kinesin superfamily motor proteins and intracellular transport. Nat Rev Mol Cell Biol 10:682-696. CrossRef Medline

Horesh D, Sapir T, Francis F, Caspi M, Grayer Wolf SG, Elbaum M, Chelly J, Reiner O (1999) Doublecortin, a stabilizer of microtubules. Hum Mol Genet 8:1599-1610. CrossRef Medline

Horiguchi K, Hanada T, Fukui Y, Chishti AH (2006) Transport of PIP3 by GAKIN, a kinesin-3 family protein, regulates neuronal cell polarity. J Cell Biol 174:425-436. CrossRef Medline

Jonsson U, Malmqvist M (1992) Real time biospecific interaction analysis: the integration of surface plasmon resonance detection, general biospecific interface chemistry, and microfluidics into one analytical system. In: Advances in biosensors (Turner A, ed), pp 291-336. London: JAI.

Kamimoto T, Zama T, Aoki R, Muro Y, Hagiwara M (2001) Identification of a novel kinesin-related protein, KRMP1, as a target for mitotic peptidyl-prolyl isomerase Pin1. J Biol Chem 276:37520-37528. CrossRef Medline

Kanehira M, Katagiri T, Shimo A, Takata R, Shuin T, Miki T, Fujioka T, Nakamura Y (2007) Oncogenic role of MPHOSPH1, a cancer-testis antigen specific to human bladder cancer. Cancer Res 67:3276-3285. CrossRef Medline

Kaplan A, Reiner O (2011) Linking cytoplasmic dynein and transport of Rab8 vesicles to the midbody during cytokinesis by the doublecortin domain-containing 5 protein. J Cell Sci 124:3989-4000. CrossRef Medline

Kholmanskikh SS, Dobrin JS, Wynshaw-Boris A, Letourneau PC, Ross ME (2003) Disregulated RhoGTPases and actin cytoskeleton contribute to the migration defect in Lis1-deficient neurons. J Neurosci 23:86738681. Medline

Kholmanskikh SS, Koeller HB, Wynshaw-Boris A, Gomez T, Letourneau PC, Ross ME (2006) Calcium-dependent interaction of Lis1 with IQGAP1 
and Cdc42 promotes neuronal motility. Nat Neurosci 9:50-57. CrossRef Medline

Konno D, Shioi G, Shitamukai A, Mori A, Kiyonari H, Miyata T, Matsuzaki F (2008) Neuroepithelial progenitors undergo LGN-dependent planar divisions to maintain self-renewability during mammalian neurogenesis. Nat Cell Biol 10:93-101. CrossRef Medline

Kriegstein AR, Noctor SC (2004) Patterns of neuronal migration in the embryonic cortex. Trends Neurosci 27:392-399. CrossRef Medline

Lei Y, Warrior R (2000) The drosophila lissencephaly1 (DLis1) gene is required for nuclear migration. Dev Biol 226:57-72. CrossRef Medline

Liu Z, Xie T, Steward R (1999) Lis1, the Drosophila homolog of a human lissencephaly disease gene, is required for germline cell division and oocyte differentiation. Development 126:4477-4488. Medline

Liu Z, Steward R, Luo L (2000) Drosophila Lis1 is required for neuroblast proliferation, dendritic elaboration and axonal transport. Nat Cell Biol 2:776-783. CrossRef Medline

LoTurco JJ, Bai J (2006) The multipolar stage and disruptions in neuronal migration. Trends Neurosci 29:407-413. CrossRef Medline

Malmqvist M (1993) Biospecific interaction analysis using biosensor technology. Nature 361:186-187. CrossRef Medline

Matsuda T, Cepko CL (2007) Controlled expression of transgenes introduced by in vivo electroporation. Proc Natl Acad Sci U S A 104:10271032. CrossRef Medline

Matsumoto-Taniura N, Pirollet F, Monroe R, Gerace L, Westendorf JM (1996) Identification of novel M phase phosphoproteins by expression cloning. Mol Biol Cell 7:1455-1469. Medline

McConnell SK (1991) The generation of neuronal diversity in the central nervous system. Annu Rev Neurosci 14:269-300. CrossRef Medline

Mejia-Gervacio S, Murray K, Sapir T, Belvindrah R, Reiner O, Lledo PM (2012) MARK2/Par-1 guides the directionality of neuroblasts migrating to the olfactory bulb. Mol Cell Neurosci 49:97-103. Medline

Ménager C, Arimura N, Fukata Y, Kaibuchi K (2004) PIP3 is involved in neuronal polarization and axon formation. J Neurochem 89:109-118. CrossRef Medline

Miki H, Okada Y, Hirokawa N (2005) Analysis of the kinesin superfamily: insights into structure and function. Trends Cell Biol 15:467-476. CrossRef Medline

Miyata T, Kawaguchi A, Okano H, Ogawa M (2001) Asymmetric inheritance of radial glial fibers by cortical neurons. Neuron 31:727-741. CrossRef Medline

Moores CA, Perderiset M, Francis F, Chelly J, Houdusse A, Milligan RA (2004) Mechanism of microtubule stabilization by doublecortin. Mol Cell 14:833-839. CrossRef Medline

Moores CA, Perderiset M, Kappeler C, Kain S, Drummond D, Perkins SJ, Chelly J, Cross R, Houdusse A, Francis F (2006) Distinct roles of doublecortin modulating the microtubule cytoskeleton. EMBO J 25:44484457. CrossRef Medline

Morin X, Jaouen F, Durbec P (2007) Control of planar divisions by the G-protein regulator LGN maintains progenitors in the chick neuroepithelium. Nat Neurosci 10:1440-1448. CrossRef Medline

Morris NR, Efimov VP, Xiang X (1998) Nuclear migration, nucleokinesis and lissencephaly. Trends Cell Biol 8:467-470. CrossRef Medline

Myers KA, Baas PW (2007) Kinesin-5 regulates the growth of the axon by acting as a brake on its microtubule array. J Cell Biol 178:1081-1091. CrossRef Medline

Nadarajah B, Brunstrom JE, Grutzendler J, Wong RO, Pearlman AL (2001) Two modes of radial migration in early development of the cerebral cortex. Nat Neurosci 4:143-150. CrossRef Medline

Nadarajah B, Alifragis P, Wong RO, Parnavelas JG (2002) Ventricledirected migration in the developing cerebral cortex. Nat Neurosci 5:218-224. CrossRef Medline

Nadarajah B, Alifragis P, Wong RO, Parnavelas JG (2003) Neuronal migration in the developing cerebral cortex: observations based on real-time imaging. Cereb Cortex 13:607-611. CrossRef Medline

Nadar VC, Ketschek A, Myers KA, Gallo G, Baas PW (2008) Kinesin-5 is essential for growth-cone turning. Current Biol 18:1972-1977. CrossRef Medline

Niethammer M, Smith DS, Ayala R, Peng J, Ko J, Lee MS, Morabito M, Tsai LH (2000) NUDEL is a novel Cdk5 substrate that associates with LIS1 and cytoplasmic dynein. Neuron 28:697-711. CrossRef Medline

Ohno H, Stewart J, Fournier MC, Bosshart H, Rhee I, Miyatake S, Saito T, Gallusser A, Kirchhausen T, Bonifacino JS (1995) Interaction of tyrosine-based sorting signals with clathrin-associated proteins. Science 269:1872-1875. CrossRef Medline

Ohno H, Fournier MC, Poy G, Bonifacino JS (1996) Structural determinants of interaction of tyrosine-based sorting signals with the adaptor medium chains. J Biol Chem 271:29009-29015. CrossRef Medline

Raghavan M, Bjorkman PJ (1995) BIAcore: a microchip-based system for analyzing the formation of macromolecular complexes. Structure 3:331333. CrossRef Medline

Rain JC, Selig L, De Reuse H, Battaglia V, Reverdy C, Simon S, Lenzen G, Petel F, Wojcik J, Schächter V, Chemama Y, Labigne A, Legrain P (2001) The protein-protein interaction map of Helicobacter pylori. Nature 409:211215. CrossRef Medline

Rakic P (1972) Mode of cell migration to the superficial layers of fetal monkey neocortex. J Comp Neurol 145:61-83. CrossRef Medline

Reiner O (2000) LIS1: let's interact sometimes...(part 1). Neuron 28:633636. CrossRef Medline

Reiner O, Sapir T (2009) Polarity regulation in migrating neurons in the cortex. Mol Neurobiol 40:1-14. CrossRef Medline

Sapir T, Elbaum M, Reiner O (1997) Reduction of microtubule catastrophe events by LIS1, platelet-activating factor acetylhydrolase subunit. EMBO J 16:6977-6984. CrossRef Medline

Sapir T, Sapoznik S, Levy T, Finkelshtein D, Shmueli A, Timm T, Mandelkow EM, Reiner O (2008a) Accurate balance of the polarity kinase MARK2/ Par-1 is required for proper cortical neuronal migration. J Neurosci 28: 5710-5720. CrossRef Medline

Sapir T, Shmueli A, Levy T, Timm T, Elbaum M, Mandelkow EM, Reiner O (2008b) Antagonistic effects of doublecortin and MARK2/Par-1 in the developing cerebral cortex. J Neurosci 28:13008-13013. CrossRef Medline

Sasaki S, Shionoya A, Ishida M, Gambello MJ, Yingling J, Wynshaw-Boris A, Hirotsune S (2000) A LIS1/NUDEL/cytoplasmic dynein heavy chain complex in the developing and adult nervous system. Neuron 28:681-696. CrossRef Medline

Shi SH, Jan LY, Jan YN (2003) Hippocampal neuronal polarity specified by spatially localized mPar3/mPar6 and PI 3-kinase activity. Cell 112: 63-75. CrossRef Medline

Shimada T, Toriyama M, Uemura K, Kamiguchi H, Sugiura T, Watanabe N, Inagaki N (2008) Shootin1 interacts with actin retrograde flow and L1CAM to promote axon outgrowth. J Cell Biol 181:817-829. CrossRef Medline

Shmueli A, Gdalyahu A, Sapoznik S, Sapir T, Tsukada M, Reiner O (2006) Site-specific dephosphorylation of doublecortin (DCX) by protein phosphatase 1 (PP1). Mol Cell Neurosci 32:15-26. CrossRef Medline

Smith DS, Niethammer M, Ayala R, Zhou Y, Gambello MJ, WynshawBoris A, Tsai LH (2000) Regulation of cytoplasmic dynein behaviour and microtubule organization by mammalian Lis1. Nat Cell Biol 2:767-775. CrossRef Medline

Swan A, Nguyen T, Suter B (1999) Drosophila Lissencephaly-1 functions with Bic-D and dynein in oocyte determination and nuclear positioning. Nat Cell Biol 1:444-449. CrossRef Medline

Tabata H, Nakajima K (2003) Multipolar migration: the third mode of radial neuronal migration in the developing cerebral cortex. J Neurosci 23:9996-10001. Medline

Tabata H, Kanatani S, Nakajima K (2009) Differences of migratory behavior between direct progeny of apical progenitors and basal progenitors in the developing cerebral cortex. Cereb Cortex 19:2092-2105. CrossRef Medline

Tamamaki N, Nakamura K, Okamoto K, Kaneko T (2001) Radial glia is a progenitor of neocortical neurons in the developing cerebral cortex. Neurosci Res 41:51-60. CrossRef Medline

Terabayashi T, Itoh TJ, Yamaguchi H, Yoshimura Y, Funato Y, Ohno S, Miki H (2007) Polarity-regulating kinase partitioning-defective 1/microtubule affinity-regulating kinase 2 negatively regulates development of dendrites on hippocampal neurons. J Neurosci 27:13098-13107. CrossRef Medline

Tint I, Jean D, Baas PW, Black MM (2009) Doublecortin associates with microtubules preferentially in regions of the axon displaying actin-rich protrusive structures. J Neurosci 29:10995-11010. CrossRef Medline

Toriyama M, Shimada T, Kim KB, Mitsuba M, Nomura E, Katsuta K, Sakumura Y, Roepstorff P, Inagaki N (2006) Shootin1: a protein involved in the organization of an asymmetric signal for neuronal polarization. J Cell Biol 175:147-157. CrossRef Medline 
Toriyama M, Sakumura Y, Shimada T, Ishii S, Inagaki N (2010) A diffusionbased neurite length-sensing mechanism involved in neuronal symmetry breaking. Mol Syst Biol 6:394. Medline

Toriyama M, Kozawa S, Sakumura Y, Inagaki N (2013) Conversion of a signal into forces for axon outgrowth through Pak1-mediated Shootin1 phosphorylation. Curr Biol 23:529-534. CrossRef Medline

Tsukada M, Prokscha A, Ungewickell E, Eichele G (2005) Doublecortin association with actin filaments is regulated by Neurabin II. J Biol Chem 280:11361-11368. CrossRef Medline

Tsukada M, Prokscha A, Eichele G (2006) Neurabin II mediates doublecortin-dephosphorylation on actin filaments. Biochem Biophys Res Commun 343:839-847. CrossRef Medline

Várnai P, Balla T (1998) Visualization of phosphoinositides that bind pleckstrin homology domains: calcium- and agonist-induced dynamic changes and relationship to myo-[3H]inositol-labeled phosphoinositide pools. J Cell Biol 143:501-510. CrossRef Medline

Veniere S, Ampe C, Vandekerckhove J, Lambrechts A (2009) The interaction of proline-rich ligands with profilin probed with an enzyme-linked immunosorbent assay. J Biomol Screen 14:350-359. CrossRef Medline

Vojtek AB, Hollenberg SM (1995) Ras-Raf interaction: two-hybrid analysis. Methods Enzymol 255:331-342. CrossRef Medline

Watabe-Uchida M, John KA, Janas JA, Newey SE, Van Aelst L (2006) The
Rac activator DOCK7 regulates neuronal polarity through local phosphorylation of Stathmin/Op18. Neuron 51:727-739. CrossRef Medline

Westendorf JM, Rao PN, Gerace L (1994) Cloning of cDNAs for M-phase phosphoproteins recognized by the MPM2 monoclonal antibody and determination of the phosphorylated epitope. Proc Natl Acad Sci U S A 91:714-718. CrossRef Medline

Williams RC (1992) Analysis of microtubule dynamics in vitro. In: The cytoskeleton, a practical approach (Carraway KL, Carraway CAC, eds), pp 151-166. Oxford: IRL.

Wojcik J, Boneca IG, Legrain P (2002) Prediction, assessment and validation of protein interaction maps in bacteria. J Mol Biol 323:763-770. CrossRef Medline

Xiang X, Osmani AH, Osmani SA, Xin M, Morris NR (1995) NudF, a nuclear migration gene in Aspergillus nidulans, is similar to the human LIS-1 gene required for neuronal migration. Mol Biol Cell 6:297310. Medline

Yoon SY, Choi JE, Huh JW, Hwang O, Lee HS, Hong HN, Kim D (2005) Monastrol, a selective inhibitor of the mitotic kinesin Eg5, induces a distinctive growth profile of dendrites and axons in primary cortical neuron cultures. Cell Motil Cytoskeleton 60:181-190. CrossRef Medline

Zochodne DW, Auer R, Fritzler MJ (2003) Longstanding ataxic demyelinating polyneuronopathy with a novel autoantibody. Neurology 60 : 127-129. CrossRef Medline 